1II) Nordic Council of Ministers

Higher

Ecueorion

ine reares

countases

Collaboration, Specialisation and Concentration (CSC)

within vulnerable academic areas 



\section{Higher Education in the Nordic Countries}

Collaboration, Specialisation and Concentration (CSC) within vulnerable academic areas

TemaNord 2017:529 
Higher Education in the Nordic Countries

Collaboration, Specialisation and Concentration (CSC) within vulnerable academic areas

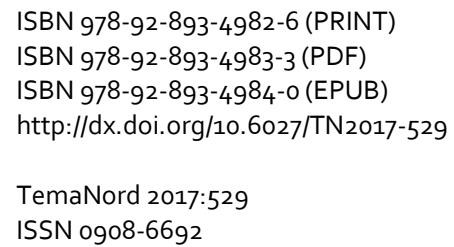

(c) Nordic Council of Ministers 2017

Cover photo: Norden.org/Yadid Levi

Print: Rosendahls

Printed in Denmark

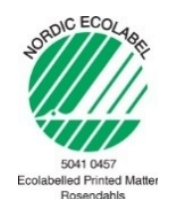

Although the Nordic Council of Ministers funded this publication, the contents do not necessarily reflect its views, policies or recommendations.

\section{Nordic co-operation}

Nordic co-operation is one of the world's most extensive forms of regional collaboration, involving Denmark, Finland, Iceland, Norway, Sweden, the Faroe Islands, Greenland, and Åland.

Nordic co-operation has firm traditions in politics, the economy, and culture. It plays an important role in European and international collaboration, and aims at creating a strong Nordic community in a strong Europe.

Nordic co-operation seeks to safeguard Nordic and regional interests and principles in the global community. Shared Nordic values help the region solidify its position as one of the world's most innovative and competitive. 


\section{Contents}

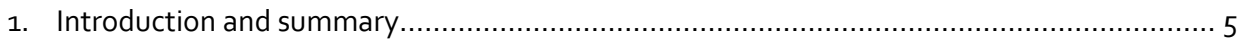

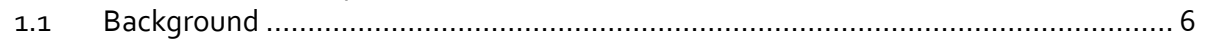

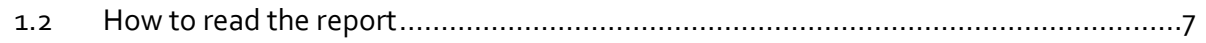

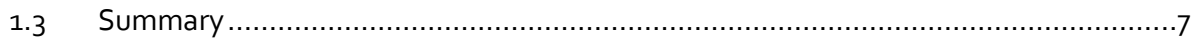

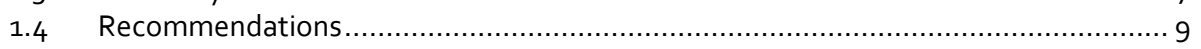

2. Frameworks for CSC initiatives for vulnerable subjects..........................................15

2.1 Definition of Collaboration, Specialisation and Concentration (CSC)....................15

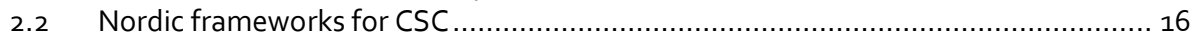

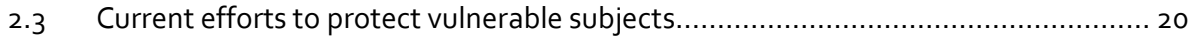

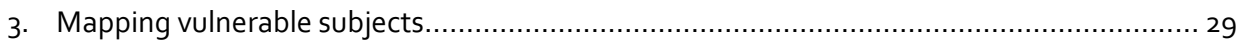

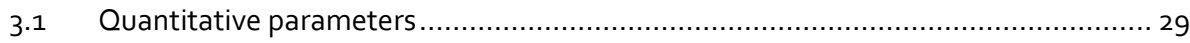

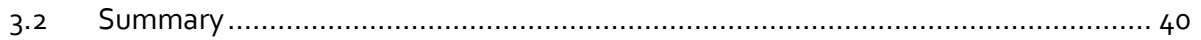

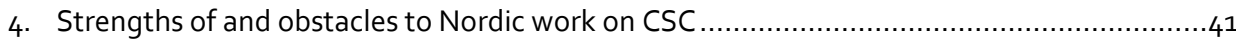

4.1 Characteristics of vulnerable subjects across the Nordic countries .........................41

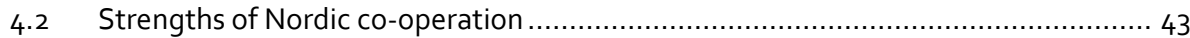

4.3 Challenges associated with collaboration ................................................. 45

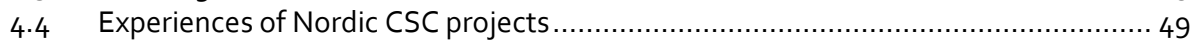

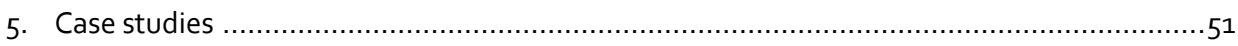

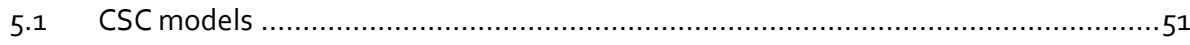

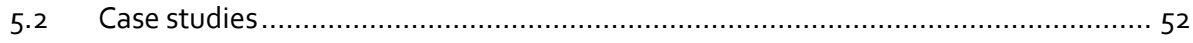

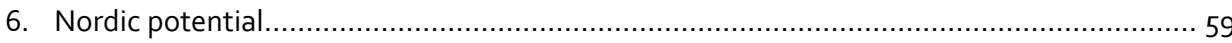

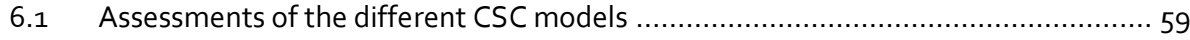

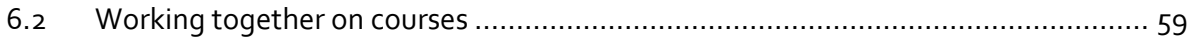

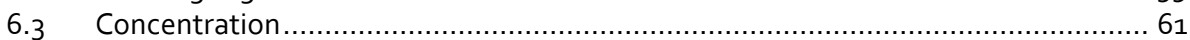

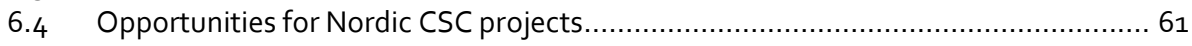

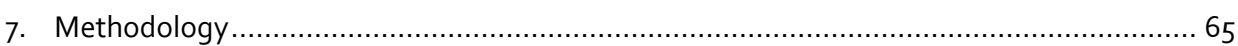

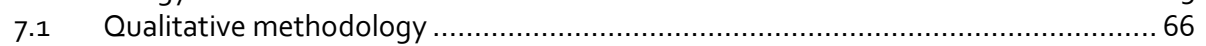

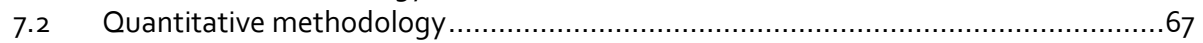

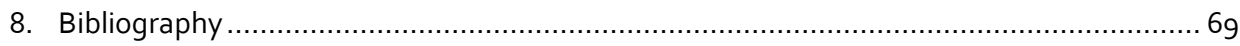

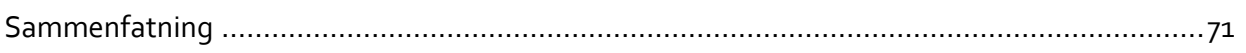

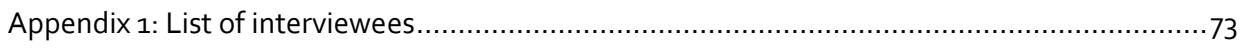

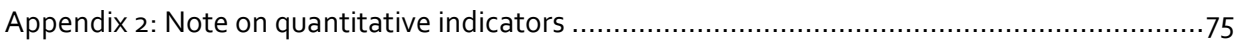

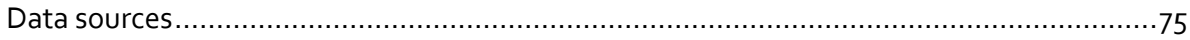

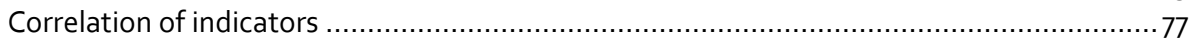

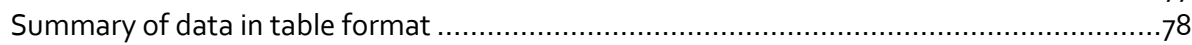

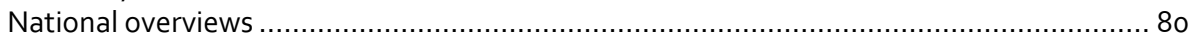





\section{Introduction and summary}

The Nordic countries wish to work together to create sustainable and high-quality educational environments (Nordic Council of Ministers ad hoc Group for Quality in Higher Education, 2015). This ambition also applies to vulnerable subject areas, in which it can be difficult to maintain an academic environment of high quality at national level. Based on these ambitions, the objective of this study is to map existing vulnerable subject areas and explore the potential for enhanced Collaboration, Specialisation or Concentration (CSC) $)^{1}$ of humanities programmes in the Nordic countries.

The study was conducted against the backdrop of a Nordic debate on the financial viability and strategic importance of the humanities. The debate revolves around the fact that certain academic and research environments find themselves in a position where they are both small and vulnerable. Some of them are also struggling with fluctuating intake and high dropout rates, which can make it difficult for them to remain financially viable. However, many of these subjects are strategically important for society as a whole, insofar as they help preserve aspects of national and Nordic culture and promote cultural and linguistic relationships with countries outside the Region. Nonetheless, if they fail to bridge the gap between financial viability and quality, they risk closure. In this light, it is important to look at ways in which work on CSC might help vulnerable subjects and programmes. This study aims, therefore, to examine the potential inherent in utilising this "burning platform".

The Nordic countries have a lot in common. We share the same values and culture in education, and vulnerable subjects face many of the same challenges across the Region. This makes it advantageous for us to work together on enhancing Nordic competencies and competitiveness and to generate Nordic added value by working together on these vulnerable subject areas. A Nordic approach will generate synergies that would not be possible to achieve at national level. Nordic work on CSC can help overcome the challenges faced by vulnerable study programmes all over the Region. From this starting point, the study looks at how work on CSC can help maintain sustainable, high-quality study programmes throughout the Nordic Region.

\footnotetext{
${ }^{1}$ We define collaboration as a situation in which two or more academic environments work together. Specialisation is defined as when two or more (equal-sized) subject areas work together, but each has a different academic and research focus. Concentration is defined as bringing academic environments together under the same umbrella in such a way that all of the research and teaching is done at a single site, or as few places as possible.
} 


\subsection{Background}

The Norwegian (2012), Danish (2015) and current Finnish presidencies of the Nordic Council of Ministers have all sought to generate Nordic added value by developing closer collaboration between small academic subject areas throughout the Region. This work started in 2012, when the Norwegian Presidency hosted a conference of university rectors and deans of humanities faculties from the capital cities, the purpose of which was to consider tangible proposals for greater Nordic co-operation. A meeting in 2012 between the Research Committee of the Norwegian Association of Higher Education Institutions and representatives of the European University Association (UHR) and the Association of Nordic University Rectors' Conferences (NUS) concluded that there was great potential in close collaboration between the Nordic higher education institutions (HEls). The Nordic countries share a number of strengths, and bringing them together could lead to a range of synergies. Nordic added value can be generated via collaboration between vulnerable subject areas. This will lead to:

- support for Nordic positions of strength

- quantifiable synergies compared to national approaches

- the manifestation and enhancement of the Nordic sense of affinity

- enhancement of Nordic competencies and competitiveness

- stronger Nordic influence at international level.

Efforts to generate Nordic added value should not be restricted to collaboration between vulnerable subject areas in HEls. In the longer term, it should also be about joint priorities for the number of academic environments that the Nordic HEls can support; which subjects it is politically expedient to support; whether "specialisation" involving multiple HEls may be more appropriate; and what subject areas are no longer viable or for which there is no longer sufficient demand.

Since 2012, a range of activities, conferences and meetings have sought to identify and develop both potential and specific proposals for closer Nordic co-operation on the range of vulnerable subjects available in the Region, including language subjects, in order to guarantee their survival. In 2012, the Norwegian Presidency and NUS held a conference to flesh out the potential for joint thinking and Nordic co-operation in three areas: Collaboration, Specialisation and Concentration (CSC).

In 2012, the Nordic Council of Ministers for Education and Research (MR-U) set up an ad hoc working group with a remit to present proposals on ways to promote collaboration, specialisation and concentration (CSC), for example on small humanities subjects. 


\subsection{How to read the report}

The main points and findings are summarised in Chapter 2.

Chapter 3 looks at what constitutes a vulnerable subject area, culminating in a definition of vulnerable programmes in the humanities. This was achieved by settling on qualitative and quantitative criteria and then qualifying them via desk research and interviews with representatives of government ministries, deans, associate deans, heads of departments and heads of study.

Chapter 4 contains a complete quantitative mapping exercise of vulnerable subjects in the Nordic Region. It looks at the following quantitative parameters: intake, dropout rate, completion time, completion rate, student numbers and number of academic staff. The purpose of the mapping exercise is to provide a basis for comparison and interaction between the vulnerable programmes.

Chapter 5 presents existing national and Nordic co-operation, as identified by desk research and interviews. It also highlights the shared features of vulnerable programmes throughout the Region, as well as the strengths and challenges to be found in working on CSC at Nordic level.

On the basis of this work, we have identified a number of models for collaboration, which are outlined in Chapter 6 in four in-depth case studies of the suitability of various types of work on CSC.

Chapter 7 evaluates the applicability of the various models and the potential for work on CSC initiatives.

This study repeatedly refers to the concept of "vulnerable" subjects (or vulnerable study programmes) rather than just "small" subjects". This is because some small subjects are sustainable and able to maintain high levels of educational and research quality, and others work with partners to offer a wide range of study programmes and a stable level of research. If we exclusively focus on "small" subjects, the definition would exclude larger ones that are vulnerable and include small but robust ones. These were among the points taken into account when the Norwegian National Faculty Meeting for the Humanities chose to use the adjective "vulnerable" rather than "small". The point at which an academic environment is considered small also varies. In the smaller Nordic societies - the Faroe Islands, Åland and Greenland - the threshold at which a study programme is considered small may be lower than in the bigger countries and they may have less need of a special small-subject scheme. In line with the Norwegian National Faculty Meeting, we believe it is more useful to use the concept of "vulnerable" subjects in this study.

\subsection{Summary}

In the current economic climate, many study programmes are vulnerable and at risk of closure, for example due to limited intake, often combined with high dropout rates. They struggle to achieve critical mass and are under financial and academic pressure due to high unit costs per student. The subjects concerned may have cultural and 
socioeconomic value, but at the moment there is neither the will nor the money to allocate significant resources to them. In addition, certain countries do not wish to see significantly higher intake on vulnerable programmes. Based on the above, the study looked at how to boost vulnerable programmes by means of Nordic work on CSC.

For the purposes of this study, vulnerable study programmes are defined as those on a level equivalent to EOF 6 or 7 with a dropout rate higher than $30 \%$, and with an intake of fewer than 20 students per annum if they are on EQF level 6 or fewer than 10 on EQF level 7. The definition was drawn up to serve as a basis for discussing vulnerable study programmes throughout the region and their potential for Nordic CSC initiatives.

The desk research and interviews with representatives of the Nordic ministries indicate significant differences in the extent to which higher education institutions (HEls) in Sweden, Denmark, Norway, Finland, Iceland, the Faroe Islands, Greenland and Åland focus on collaboration, specialisation and concentration of academic environments as a solution to the problem. On the other hand, the fact that vulnerable humanities subjects across the Region have certain characteristics in common means that there is also great potential for more work on CSC, for example on issues such as critical mass, sustainable financing, study environment and internationalisation.

The associate deans, deans, lecturers, heads of department and heads of study interviewed emphasised that work on CSC can be used to reinforce vulnerable study programmes and meet the challenges they face throughout the Region. The strength of CSC at Nordic level is that it provides greater breadth and weight to the vulnerable subjects. It can also help to develop the subject concerned, establish Nordic networks, foster internationalisation, improve finances via economies of scale and generate Nordic added value.

However, there are certain barriers to Nordic CSC initiatives. Firstly, differences in national frameworks and institution-specific regulations make collaboration difficult. Secondly, the initial financial investment needed to facilitate collaboration can be an obstacle, as there may be significant costs associated with getting it off the ground, for example for administrative work. Thirdly, experience shows that concentration of academic environments can be difficult because HEls often prefer to keep them inhouse. Internal competition and the desire of HEls to maintain their autonomy also serve as obstacles. All of these obstacles, and the reluctance of HEls, make it difficult to bolster vulnerable subjects via the type of work on CSC that would ensure their survival.

Based on the characteristics shared by the vulnerable subjects and the strengths and weaknesses of adopting an approach based on collaboration, specialisation and concentration, we looked at what models for collaboration lecturers, heads of department and heads of study in vulnerable subjects think would be the most viable and useful. Our desk research and interviews identified four models of collaboration. They are based on real-world case studies of successful work on CSC that could be applied to other vulnerable subjects. The cases show that work on CSC can generate considerable benefits. The models we identified are collaboration on courses; collaboration on language subjects with universities in the country where the language is spoken; joint master's study programmes (EOF level 7); and concentration by bringing academic environments together under the same umbrella. The vulnerable 
academic environments think that collaboration on courses and joint master's programmes are particularly useful models that could be applied to their subject areas. However, both of these types of collaboration require mobility on the part of students and lecturers, and that can be a challenge. Online courses and mobility funding are highlighted as instruments for dealing with this challenge. Collaboration on language subjects with universities in the country where the language is spoken is seen as a good model, but is only relevant for language subjects. The lecturers, heads of department and heads of study interviewed also emphasised that while concentration has its advantages, it needs to be organised and co-ordinated at ministerial or Nordic level.

In general, representatives of vulnerable subjects see great potential in Nordic CSC initiatives, particularly at master's level (EQF 7), where reaching critical mass is more of a challenge. They emphasise that work on CSC can help develop their subject areas, strengthen the Scandinavian languages, enhance quality, provide greater diversity and increase student numbers. However, as previously noted, there are still a number of obstacles to be overcome, including bureaucratic challenges, lack of funding and internal resistance within HEls. If these barriers can be overcome, work on CSC will lead to benefits for students, the academic environments, HEls and Nordic society. In this report, we have drawn up a series of recommendations to help minimise the obstacles identified in the study.

\subsection{Recommendations}

\subsubsection{Higher education institutions}

\section{Collaboration on courses ensures greater diversity}

The study shows that collaboration on courses ensures breadth in the range of subjects available and makes it possible to develop courses that individual universities might not be able to set up on their own. Working together on courses utilises core academic competencies across the Nordic Region and can help develop new areas within the subject concerned. It also preserves the academic and research environment at the HEls involved, which means that it is easy to secure backing for this type of collaboration in the departments. It is an advantage for departments to work together on joint courses that will enhance the diversity of the programmes they offer. As demonstrated by the East European Studies case study (see Section 5.2), joint courses can focus on thematic problems.

\section{Joint programmes}

Joint Nordic programmes can strengthen vulnerable subjects by drawing on expertise at the HEls involved. This type of collaboration makes it possible to offer more courses to students and to attract guest lecturers from other Nordic countries. Joint programmes also make it possible to preserve narrow subject areas through multiple HEls working together and complementing each other. In addition, the students improve their employment prospects by getting to know a range of international 
environments. Joint programmes also facilitate the internationalisation of subjects and make them more visible globally. We therefore recommend that vulnerable study programmes in Nordic departments join forces to establish joint programmes. One example of how to organise this type of collaboration is presented in the Viking and Medieval Norse Studies case study (see Section 5.2), on which the first two semesters are spent at one of the universities involved and students can then choose to take the third and fourth semesters at one of the other universities. This particular programme is an example of the Nordic Master Programme, which is co-funded by the Nordic Council of Ministers.

Collaboration on languages in the countries where they are spoken The majority of the programmes that fall under our definition of vulnerable are in language subjects, which makes collaborating with the country in which the language is spoken an advantage. It provides students with the opportunity to improve their language skills and gain insights into the cultural and historical context of the country. The China Studies case study (see Section 5.2), is an example of a partnership with a university in the country where the language is spoken, which has been extended into a Nordic collaboration. Working together makes it possible to assure the quality of courses by drawing on research and lecturers from different Nordic HEls. China Studies also represents an example of how this type of collaboration can be organised. The first and fourth semesters are spent at one of the Nordic universities, while the second and third semesters are spent at the university in the country where the language is spoken.

\section{Sharing knowledge highlights value of Nordic CSC initiatives}

It is important that both staff and management see the value of work on CSC. They must be made aware of the considerable benefits of working with other Nordic departments and similar study programmes. This can be done by sharing knowledge of existing, successful models for collaboration, for example based on the models identified in this study. These models can serve as sources of inspiration for vulnerable study programmes and for disseminating knowledge in the departments. We also recommend setting up a platform where senior management from Nordic universities can meet and share knowledge and experience of CSC initiatives. The current bodies the Association of Nordic University Rectors Conferences (NUS) and the Nordic Association of University Administrators (NUAS) - already play an important part in Nordic co-operation on education, but the level of coordination under their auspices could be strengthened further. One way of doing this would be via a Nordic forum for rectors, where the senior management of HEls could meet to discuss and streamline their regulations in order to facilitate collaboration at Nordic level. The core of such a forum could be based on existing contacts between universities in the capital cities in 
the humanities. An alternative source of inspiration might be Nordic 5 Tech, a formal collaboration between five technical universities. ${ }^{2}$

\section{Efficient administration facilitates work on CSC}

The administrative work associated with reaching agreements to set up and run collaborations between multiple HEls makes collaboration between vulnerable programmes expensive. Often, they see the financial costs of working on CSC as a barrier. For HEls to feel motivated to enter into collaboration agreements, it is important that their costs do not rise. Incentives are called for. The parties involved need help to establish agreements so that they are not perceived as an additional cost and workload. One tangible way of reducing the administrative burden would be to make one of the HEls involved responsible for all of the administration. This institution would receive a portion of the budget for administration and could employ staff specifically to handle the overall administration needs. This would ease the burden on the other partners in the collaboration.

\subsubsection{Ministries}

Improving CSC work by streamlining administration and legislation

Administrative frameworks and national legislation pose difficulties for collaboration across subjects, HEls and countries. The Nordic countries have different accreditation requirements and quality-assurance programmes, term/semester structures and forms of examination, as well as different ministerial and executive orders on the content and type of teaching. ${ }^{3}$ Attention needs to be paid at political level to the challenges that represent obstacles to collaboration between Nordic HEls. With this in mind, we recommend that guidelines are drawn up at ministerial level that lay down the frameworks for collaboration across the Region. Aligning national administrative frameworks at Nordic level would facilitate collaboration between HEls. Streamlining national regulations in higher education, for example accreditation requirements, would be a further boost to collaboration and facilitate the establishment of joint programmes.

\section{Political incentives for CSC initiatives need management support}

Many of the existing partnerships mapped out by the study took a bottom-up approach and were initiated by enthusiastic academics. However, some of them have found that it can be a long way from initial idea to final agreement unless management prioritises collaboration. The self-interest of HEls further complicates work on CSC. It was pointed out during the study, including in the interviews, that lecturers - both for competitive

\footnotetext{
${ }^{2}$ Nordic Five Tech is a strategic alliance of the five leading technical universities in the Nordic countries: Aalto University in Finland, Chalmers University of Technology in Sweden, Technical University of Denmark, KTH Royal Institute of Technology in Sweden and Norwegian University of Science and Technology. 3 The "Joint Degrees and the Nordic Countries" report, subtitled "Nordic Master Programme: Legal and administrative obstacles", details the challenges of establishing joint Nordic study programmes from an administrative and legislative perspective. Nordic Council of Ministers 2015 TemaNord2015: 528.
} 
reasons and due to work-related pressures - are often inclined to prioritise their own academic networks within the HEI concerned rather than Nordic partnerships. It is, therefore, of great importance that HEl management sees the value of Nordic work on CSC, and helps communicate that value to staff while still remaining open to ideas coming from below. Against a backdrop of spending cuts and increasing demands on HEls, several interviewees felt that collaboration agreements shifted their focus away from their primary roles. To counteract this, we recommend political incentives to establish collaboration with a view to improving the HEls' academic and financial position in the long term, for example start-up grants or subsidies for successful agreements.

Nordic strategy for the concentration of vulnerable subjects

The study found that concentration is the most difficult aspect of the work on CSC. The reason for this is that successful academic concentration is generally a long-term process that requires major changes. It is made difficult by factors such as the HEls' internal competition and their desire for autonomy. Concentration entails the closure of whole academic environments, which can lead to disagreements on subject prioritisation. We recommend, as per the suggestions from some of the HEls interviewed, that the concentration of vulnerable subjects is organised at ministerial level, as is currently the case, for example, in Finland and Norway. For concentration to succeed, government must be at the forefront of the process. Similarly, a Nordic approach to vulnerable subjects may also be necessary as a starting point for preliminary discussions regarding a Nordic concentration strategy.

\subsubsection{The Nordic Council of Ministers}

Mobility funding can increase student mobility

The study highlighted that geographical distance is a challenge for Nordic cooperation. Mobility - for both students and lecturers - is a prerequisite for joint programmes. Some Danish HEls pointed out that the Study Progress Reform ${ }^{4}$ has made it more difficult for students to take part of their study programme abroad, as they risk undermining their own financial situation or losing their study place. It might, therefore, be a positive step for the Nordic Council of Ministers (NCM) to make more mobility funding available to students on the Nordic Master Programme (NMP) and within the Nordplus scheme, in the same way as existing Erasmus scholarships are provided for Erasmus students. This would enhance student mobility and provide financial cover for study periods in other Nordic countries.

4 The Danish Study Progress Reform, adopted in 2013, aims to reduce the amount of time by which students exceed the prescribed period of study by 4.3 months (relative to the level in 2011) by 2020, when it will be fully implemented. 
Online collaboration cuts distance and costs

E-learning is one way to tackle geographical distances and overcome logistical challenges. Digital solutions offer better opportunities for HEls to work together and reduce the cost of collaboration. For example, the University of Copenhagen (KU) has been running Massive Online Open Courses (MOOCs) since 2013, experimenting with new online courses in partnership with the Coursera portal. This model can also be used in Nordic CSC initiatives, e.g. offering video lectures, online exams and academic debates in virtual forums with other students. It also offers a more flexible learning environment, one in which students do not have to relocate in order to attend classes, but fit courses in with their day-to-day lives. All of this would reduce the mobility challenges highlighted in the study. We recommend that HEls develop more digital solutions. The NCM could help HEls develop online and ensure that they have the necessary digital skills.

Stable funding for joint programmes increases the motivation to maintain collaboration

In the past, the NCM has provided one-off funding for setting up Nordic Master programmes. This meant that the academic environments involved were forced to find a sustainable funding model in order to keep the programme running for a prolonged period. According to one associate professor at $\mathrm{KU}$, this can reduce the motivation to invest energy into collaboration, because staff may have no idea whether a programme will continue in the long term. In the latest round of applications to its NMP, the Council of Ministers introduced a funding model that stretches over longer periods (up to five years) and reduces financial uncertainty. Stable funding is a crucial factor in ensuring that the parties involved in collaborations are motivated to put in the effort needed to keep them going.

\section{Systematisation improves data comparability}

The study shows that many Nordic HEls do not systematically collate educational data, and that the countries also use different definitions and categorisation for their data. This makes it difficult to draw direct comparisons between countries on parameters like academic staff numbers, budgets and dropout rates. We recommend the introduction of Nordic guidelines for systematic data acquisition. This would provide a better basis upon which to compare HEls and assess which subjects and institutions would benefit most from work on CSC. 



\section{Frameworks for CSC initiatives for vulnerable subjects}

This chapter starts by defining the concept of collaboration, specialisation and concentration as it is used in this study. We then present the existing Nordic frameworks and agreements that underpin the work done on CSC in vulnerable humanities subjects. The chapter concludes with a review of how each Nordic country approaches the issue of vulnerable subjects.

\subsection{Definition of Collaboration, Specialisation and Concentration (CSC)}

In 2012, the Norwegian Presidency and the Association of Nordic University Rectors Conferences (NUS) hosted a conference to discuss possible initiatives to encourage collaboration, specialisation and concentration (CSC) on vulnerable subjects. An ad hoc working group was set up to identify challenges to and potential initiatives for work on CSC.

For the purposes of this study it was deemed relevant to continue to develop the concept of CSC in order to differentiate between the various ways of working together. Collaboration is not always the ideal solution - it will not necessarily solve problems with small academic environments, dropout and retention rates or the financial situation.

We will begin by defining what we understand by the concept of CSC. As shown in Figure 1 below, we define collaboration as a situation in which two or more academic environments work together to offer study programmes. Collaboration is the result of multiple academic environments making a coordinated effort to perform particular tasks (Nordic Institute for Studies in Innovation, Research and Education (NIFU), 2012). The academic environments involved may well be the same size as each other and have the same academic focus, but they work together on, e.g. the range of study programmes offered, the teaching, administration, research, etc. Collaboration does not need to have a physical dimension - it can, for example, take the form of online courses. 
Figure 1: DAMVAD Analytics' definition of Collaboration, Specialisation and Concentration (CSC) 5

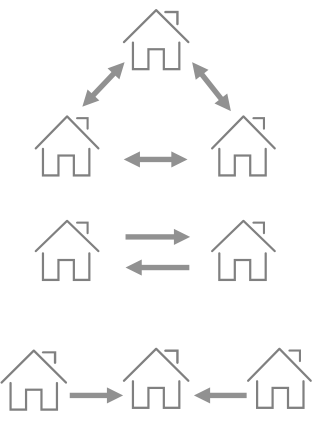

Collaboration

(The academic environments are the same size/have the same academic focus and work together on subjects, teaching, research, etc.)

\section{Specialisation}

(The academic environments are the same size but have different academic focus. They divide up the academic work that needs done between them).

\section{Concentration}

(Multiple small academic environments spread over several HEls. The aca-demic subject can be concentrated in one location by erging the various aca-demic environments).

Source: DAMVAD Analytics 2016.

Specialisation occurs when two or more (equal-sized) subject areas work together, but each has a different academic and research focus. They concentrate on their academic areas of strength, but do not teach or conduct research in precisely the same areas as each other. This means that they do not compete with each other, but complement each other's standards and together make up a strong academic environment. Specialisation is a way of reducing overlap in competencies, expertise and academic focus, and ensuring an efficient use of resources (NIFU, 2012).

Concentration of study programmes occurs when one or more big academic centres are dominant, and several similar but smaller setups cover the same subject area at other Nordic HEls. It also occurs when a number of smaller academic environments all lack the requisite critical mass to provide teaching of sufficient quality. Concentration consists of bringing these academic environments together under the same umbrella in such a way that all of the research and teaching is done in one or only a few places. This guarantees strong academic, research and study environments that make efficient use of resources, and leads to the closure of vulnerable and financially non-viable academic units. Concentration also helps overcome fragmentation by consolidating teaching activities in a single institution (NIFU, 2012).

\subsection{Nordic frameworks for CSC}

Nordic frameworks already exist that facilitate work on CSC in vulnerable humanities subjects. Below, we describe European and Nordic initiatives to harmonise educational systems and safeguard students' rights, e.g. via the European Qualifications Framework (EQF). All of these measures facilitate work on CSC. EQF permits comparability across the Nordic countries, while existing Nordic agreements ensure

5Source: Internal, DAMVAD Analytics, February 2016. 
equal rights to enrol in higher education (Danish Ministry of Higher Education and Science Research, 2016b, Nordic Region).

Nordic co-operation:

- The Nordic Council of Ministers for Education and Research (MR-U).

- The Nordic Committee of Senior Officials for Education and Research (EK-U).

- The Joint Committee for Nordic Research Councils in the Humanities and Social Sciences (NOS-HS).

Nordic agreements:

- Agreement on Admission to Higher Education.

- The Reykjavik Declaration.

- Nordic Master Programme.

- Nordplus.

- The Language Declaration.

European framework:

- European Qualifications Framework (EQF).

- Erasmust.

- The Lisbon Convention on Recognition of Qualifications.

- The Bologna Process.

\subsubsection{Nordic co-operation and agreements}

Agreement on Admission to Higher Education. In 1996, the Nordic countries concluded an agreement on access to higher education in the Region. Under it, people with permanent residence in one Nordic country are entitled to access to higher education $(\mathrm{HE})$ in other Nordic countries on an equal footing with their own citizens. ${ }^{6}$

The Reykjavik Declaration. On 9 June 2004, as an extension to the Agreement on Admission to Higher Education, the MR-U signed a declaration on the mutual recognition of exam results, partial qualifications and other proof of achievement across the Nordic countries. The Declaration is designed to ensure that prospective students in the Nordic Region are on an equal footing in terms of admission to HEls both in their own country and in any other Nordic country. If, for example, Swedish HEls no longer wish to offer a vulnerable subject, Swedish students are entitled to apply for admission to the same subject in another Nordic country because the countries have agreed to recognise each other's entrance qualifications.

${ }^{6}$ The 2012 amendment to the agreement did not alter these basic principles and equal rights. 
The Language Declaration defines areas on which the countries have agreed to focus in their national policy work. These include: the teaching of Scandinavian languages, neighbouring languages and foreign languages; parallel use of English and the main Nordic languages; and multilingual societies.

The $M R-U$ is made up of the ministers responsible for $\mathrm{HE}$ and research in all of the parts of the Nordic Region. It has overall responsibility for co-operation on education and research within the NCM. It is supported by the Nordic Committee of Senior Officials for Education and Research (EK-U), which looks after day-to-day co-operation at civil service level. MR-U meets twice a year, EK-U 4-5 times.

The Nordic Master Programme aims to make the Nordic Region more competitive and HEls more attractive to Nordic and international students. A significant aspect of this work consists of improving networking between the Nordic HEls.

Nordplus seeks to improve mobility and networking in the education sector between the Nordic and Baltic countries. In HE, Nordplus focuses on networking between HEls in the Nordic and Baltic countries via a range of activities, from student and lecturer mobility to the development of joint curricula and other forms of collaboration.

The Association of Nordic University Rectors Conferences (NUS) is made up of the Association of Swedish Higher Education (SUHF), the Danish Rectors' Conference (part of Universities Denmark), the Norwegian Association of Higher Education Institutions (UHR) and the National Rectors' Conference of Iceland (SH). NUS organises a conference for university rectors every second year.

The Joint Committee for Nordic Research Councils in the Humanities and Social Sciences (NOS-HS) consists of research councils from Denmark, Finland, Iceland, Norway and Sweden (NOS-HS-2016). NOS-HS has a remit to promote exchanges of information between the Nordic research councils. The NOS-HS board also supports collaboration between Nordic researchers by funding workshops.

\subsubsection{European framework}

The European Qualifications Framework (EOF) is used to compare qualifications from the different Nordic countries. This means that students can be offered the same level of education in all of the Nordic countries, regardless of the country in which they study for all or part of their humanities programme.

Nordic bachelor and undergraduate programmes are on Level 6 of the framework, while master's, professional master's and postgraduate programmes are on level 7 (see Table 1). 
In 2014, Erasmus Mundus became part of Erasmus+, the EU programme for education, training, youth and sport, which seeks to promote mobility, partnership and political development in Europe and beyond. Erasmus Mundus promotes mobility and cooperation in Europe in order to enhance the quality of HE. It supports European HEls that wish to run joint programmes or enter into partnerships with institutions in developing countries. It also supports students and researchers who wish to spend time abroad as part of a joint master's or a partnership programme.

The Lisbon Convention, which builds on the UNESCO/Council of Europe convention on the recognition of higher education qualifications, serves as the basis for the Nordic agreement on mutual recognition of higher education summarised in the Reykjavik Declaration.

The Lisbon Convention is based on two elements:

- Applicants with an HE qualification are entitled to have their foreign qualifications assessed in order to establish whether they fulfil the requirements for the educational or vocational area concerned.

- Foreign qualifications should be recognised unless there are significant and demonstrable differences between the qualification acquired in the country of origin and the corresponding study programme in, for example, the Nordic Region. The burden of proof that a qualification is not comparable lies with the body undertaking the assessment (an HEI or other relevant body, which is industry-specific in all of the Nordic countries).

The Lisbon Convention therefore forms the basis for the principle that a study programme or parts thereof taken in another Nordic country is valid and on a par with the host country's own programmes. As such, the Convention makes it possible for Nordic HEls to work together on CSC initiatives.

The Bologna Process is the name for the European inter-governmental programme to establish a joint system for HE programmes. The idea is to develop Europe as a single area for $\mathrm{HE}$ in which students and researchers move freely across borders. As such, the basic idea that underpins the Process is also one of the foundations for Nordic work on CSC. At present, 48 countries and organisations are involved in the Bologna Process and working to develop a unified degree structure (bachelor, master's, PhD), implement a joint ECTS-based credit system and remove barriers to mobility. 


\subsection{Current efforts to protect vulnerable subjects}

This chapter aims to illustrate the extent to which the Nordic countries operate with definitions of vulnerable subjects, and outlines the specific measures Nordic ministries are taking to protect them. Desk research and interviews with representatives from ministries indicate that several of the countries lack a clear definition of vulnerability, and as a result there is no authoritative definition at Nordic level either. Differences also exist in the extent to which the countries have national policies on vulnerable subjects and how highly they prioritise work on CSC. Certain national political priorities and initiatives affect how individual countries prioritise retaining or strengthening specific vulnerable subject areas. Some of the Nordic countries have special funding arrangements that earmark support for vulnerable subject areas, which might otherwise be difficult to maintain financially.

\subsubsection{Denmark}

Denmark has no clear definition of what constitutes a vulnerable subject. However, it does have a "small subjects scheme" that provides an indicative definition based on a number of objective criteria. Under the Danish small subjects scheme from 2011, humanities subjects taught at only one $\mathrm{HEl}$ receive additional state funding on top of their "taximeter" funding and research grants. The description of the scheme contained in the national budget in 2013 defines small subjects as those with student intake at only one HEl. The programmes usually have an intake of fewer than 20 students p.a. They receive additional funding designed to support teaching in a range of small humanities programmes. The HEls each receive a grant of DKK 1,250,000 per subject. The respective academic environments decide how to prioritise and use the funding. The scheme has helped promote specialisation and concentration, since it encourages HEls to coordinate small, vulnerable subjects in a way that guarantees they are available in at least one location in the country. The scheme only applies to the humanities, as it is usually humanities programmes that face the greatest challenges in terms of low uptake. The table shows the subjects covered by the Danish Ministry of Education and Research's small subjects scheme (Ministry of Finance, 2016). 
Table 2: The Danish small subjects scheme

$\begin{array}{ll}\text { University of Copenhagen (KU) } & \text { Eskimology* } \\ & \text { Finnish** } \\ & \text { Hebrew*** } \\ & \text { Korean } \\ & \text { Near Eastern Language and Society } \\ & \text { Ancient and Medieval India (Indology)** } \\ & \text { Persian**** } \\ & \text { Southeast Asian** } \\ & \text { Tibetan** } \\ & \text { Brazilian-Portuguese } \\ \text { Classical Philology } & \text { Modern Indian } \\ & \text { Bosnian/Serbian/Croatian } \\ & \text { Classical Studies }\end{array}$

Note: *Reopening in 2017.

$* *$ Closing.

$* * *$ Closing later (will be included in a new programme in Middle East Studies).

$* * * *$ Arabic and Persian to become a single new bachelor and master's study programme in Middle East Studies. Persian may also cease due to possible mergers. (KU, 2016).

However, as pointed out by the representative of the Agency for Higher Education (part of the Ministry of Higher Education and Science), some subjects are included under the small subjects scheme even though they do not meet the criterion of only being taught at a single HEI.

This is because there is also a strategic element to the choice of subjects, i.e. whether they are particularly important - for example, if there is a special cultural interest in maintaining subjects due to their role in relation to national heritage, or if there is commercial interest in supporting a subject that is important to the ability to export. The national strategy for language subjects in higher education, which is expected to be published in early 2017, may have an impact on the selection process. The idea behind the language strategy is to match the range of study programmes available with the demand for language skills, and specifically to ensure that foreign languages that are considered important to business, and that serve the nation's foreign-policy interests, are taught in Denmark and that research is conducted into them.

The definition used by the Ministry is based on a qualitative assessment of what constitutes a small subject. The Danish Accreditation Institution and DAMVAD expanded upon this definition in a study (2014) that looked at the strengths and potential of small humanities subjects, as well as the challenges they face. The report defines small subjects in broadly similar terms to the small subject scheme, but also includes a series of quantitative measurements, e.g. intake of fewer than 30 students. The idea was to include small humanities subjects that are taught at more than one location around the country.

The report identified five characteristics of the small subjects covered by the survey: 
- Critical mass in the educational environment: The study programmes have a low level of intake, some of them even having years in which no students enrol.

- Research base: The study programmes are based in small research environments, with just a few lecturers/researchers. The academic staff are usually involved in joint teaching or teach a single module/topic but are affiliated to another study programme.

- Collaboration with other (small) study programmes: There are several examples of academic and administrative collaboration between small subjects in the same HEI. The study identified two types of collaboration between small humanities subjects, i.e. skill-sharing and clusters. Skill-sharing involves sharing lecturers and making the best possible use of their competencies in specific subject areas on different programmes. Clusters involve single administrative units organising multiple small subjects, joint research, access to lecturers from related small programmes, specialised research expertise and less administration.

- Dropout rates: Small subjects tend to have high dropout rates in the first year of the bachelor programmes. However, the same phenomenon has not been observed on the master's programmes.

- Graduate employment: The study programmes are usually highly specialised. Employers outside of the education sector have limited knowledge of the graduates' competencies.

In summary, the Danish small subjects scheme focuses on using subsidies to strengthen subjects generally taught at only one HEl in the country. The scheme is evaluated every three years. It is due to be renegotiated in 2017, when decisions will be made about which subjects to include in the future. As this section has shown, small study programmes have a number of characteristics in common and face a number of the same challenges.

\subsubsection{Norway}

The national strategy for humanities research, presented by the Research Council of Norway in 2008, recommended mapping small subjects as a prelude to drawing up a national plan of action for sharing resources and specialisation. As part of this process, funding was earmarked for national faculty meetings ${ }^{7}$ - partnerships between similar faculties at all HEls - in order to develop activities aimed at encouraging academic work on CSC. The National Faculty Meeting for the Humanities defined the study programmes to be included in their projects as vulnerable, rather than small. The meeting considered the term "small" to be unfair, because small study programmes may well be sustainable if the size and structure matches their student numbers and relevant academic agreements on collaboration are in place. The decision was taken,

7The national faculty meetings are specialised strategic units established as collaborative bodies for faculties and similar units at member institutions of the Norwegian Association of Higher Education Institutions (UHR). 
therefore, to focus instead on vulnerable subjects. Vulnerable humanities subjects are defined as follows (National Faculty Meeting for the Humanities 2009; National Faculty Meeting for the Humanities 2014):

- Subjects that have problems recruiting students, a weak financial position and a large number of staff.

- Subject that have difficulty achieving the appropriate breadth, but upon which research in other subjects depends.

- Subjects (especially language subjects) that are important in an international context and serve national interests, but have a small recruitment base.

The Norwegian Ministry of Education and Research is aware of this definition of vulnerable subjects but does not use it, nor does the Ministry have any support schemes for small or vulnerable study programmes. However, it does recognise that a good learning environment requires a certain number of students. The Ministry has stipulated that, as a rule of thumb, it is inappropriate to run programmes with fewer than 20 students (Ministry of Education and Research, 2013a). The idea is to ensure the optimal use of resources and to provide the best possible study environment. The Regulations concerning quality assurance in higher education also state that the accreditation of academic programmes requires a large enough recruitment base to guarantee the establishment and maintenance of a satisfactory learning environment and a stable programme at the institution (Ministry of Education and Research 2013a, 2013c).

In Norway, several HEls run programmes in the same vulnerable subject areas, even though they have difficulty enrolling sufficient students and are based in relatively small academic environments with only a few members of staff. The report by the Stjernø Committee $^{8}$ (2008), which was set up by the government, highlighted the challenges associated with providing high-quality programmes that comply with international standards, given the many small academic environments spread around the country and the structure of the HE system. One advantage of Norway's decentralised HE system is accessibility, which has positive social effects in local communities. The disadvantages include challenges in relation to recruitment, internationalisation and critical mass. The Committee also pointed out that small study environments are not as productive as larger ones, which means that maintaining this educational structure is particularly demanding in terms of resources. The challenge of sustaining critical mass also applies to research, another field in which Norway faces a challenge due to the number of small and vulnerable academic environments. An evaluation conducted by the Research Council of Norway (2016) showed that many of the academic environments are not big enough to make an international impact, identify important research questions or pursue new directions in research. It also identified the fact that

${ }^{8}$ The Stjernø Committee was set up to look at the future development of higher education, and published the report NOU2008: 3 (Norwegian Official Report) Viewed as a whole - a new structure for higher education. 
there is not enough collaboration between the research environments and the HEIs, ${ }^{9}$ and that critical mass is not the only challenge - the research environment is also fragmented, with a great deal of individual research.

A number of initiatives were taken in response to the challenges outlined above. The challenges of small and vulnerable research environments and small and scattered provision of study programmes led to the 2015 Norwegian structural reform in the university and college sector (Ministry of Education and Research 2015a, 2015b). The reform concentrated funding in fewer but stronger institutions in order to improve the quality of education and research. This led to a wave of mergers, reducing the number of state universities and colleges from 33 to 21 by 2017 . The mergers are designed to meet the challenges faced by vulnerable subjects, make administration more efficient and improve shared services and digital systems in the HE sector. According to the representative of the Ministry, the mergers happened too recently to say anything definitive about the effects of the reform.

To ensure both depth and breadth in the research environment, the Norwegian Agency for Quality Assurance in Education (NOKUT), ${ }^{10}$ the Norwegian accreditation agency, has introduced the requirement that there must be at least $15 \mathrm{PhD}$ students in an institution for PhD courses to be accredited (Norwegian Ministry of Education and Research 2013b). In addition to the accreditation requirements aimed at ensuring a stable research environment, the establishment of national research schools has helped strengthen collaboration and specialisation between institutions. This in turn has helped counteract the fragmentation of the research environment. A number of institutions collaborate on $\mathrm{PhD}$ programmes in specific subject areas in order to improve recruitment, completion rates and internationalisation. The Ministry provides a total of NKK 40 million of funding per year to 15 national research schools.

The Ministry's structural reform focuses on work on CSC processes, which it sees as a way of boosting the sector as a whole and ensuring stronger and more robust academic environments. HEls are encouraged to increase specialisation and concentration, both nationally and internationally, in order to ensure a high level of both quality and relevance. Mergers with other small academic environments in the same or related subject areas in fewer institutions are designed to ensure that the environments grow bigger in size and are better prepared for development. The Ministry also urges HEls to assume special responsibility for development in particular subject areas by working together on education and research. In this way, each of the individual institutions is assured a national role. The Associate Dean of Education at the University of Oslo pointed out that concentration is a difficult process, one that requires strong will on the part of the individual academic environments - especially because in some cases more than one $\mathrm{HEl}$ will want to continue providing a particular subject.

\footnotetext{
9 It should be noted that the evaluation only included the bigger research environments, since anonymity could not be guaranteed in the smaller academic groups.

${ }^{10}$ NOKUT is an accreditation institution within the Ministry of Education and Research. Its main remit is to document and provide information on the current state of higher education, vocational training and approved study programmes abroad.
} 
The government is drafting a report to parliament on humanities research and education, which will examine the relevance of humanities content to society and the labour market, as well as its contribution to schools and teacher training. In the wake of the structural reform of HE sector, the need for national/Nordic coordination of vulnerable study programmes will be discussed.

The Ministry of Education and Research has attempted to address the challenges faced by small and vulnerable subjects, including - as mentioned above - by merging HEls. Unlike Denmark, Norway does not have a special financial scheme to help small subjects, however, the issue is high on the Ministry's agenda, and it strongly encourages HEls to promote work on CSC.

\subsubsection{Sweden}

In Sweden, national and international collaboration on the development of education and research are seen as the way to strengthen vulnerable humanities subjects. In 2010, projects were launched to promote collaboration between the HEls. Alongside these projects, a survey of faculties was introduced to map out where the need for collaboration was greatest. The work was intended to ensure strong academic environments with stable links to research (SUHF, 2009).

The University of Gothenburg operates with a loose definition of small subjects as ones with fewer than 50 students. The University has faced challenges with vulnerable language programmes with low student numbers, and has highlighted the need for work on CSC at both national and Nordic level. Another focus area in Sweden has been strengthening language subjects by digital teaching (SUHF language group, 2010; SUHF, 2009). Digitisation is designed to improve the quality of language programmes, and to promote flexibility and individualisation in teaching.

A comparative study shows that concentrating universities and research institutions in Denmark and Sweden has led to synergies between HEls. Concentrating research has a long history in Sweden, whereas in Denmark it is the result of the reform of the university and research sector in 2007, which led to a number of mergers. The reform reduced the number and increased the size of research institutions and universities, which has led to larger academic environments (Joanneum Research \& DAMVAD Analytics, 2015).

Sweden does not have any special financial schemes for small or vulnerable subjects, and the Ministry does not focus on the issue to the same extent as its counterparts in the other Nordic countries.

\subsubsection{Finland}

Finland has a large number of small subjects, including in the humanities, with many HEls reporting low student intake on humanities programmes in line with the other Nordic countries. A representative of the Finnish Ministry of Education and Culture's Department for Higher Education and Science Policy pointed out that it is a challenge that several universities run the same programmes, which means that many of the 
small subjects are spread out across multiple HEls, leading to considerable overlap in some subject areas. As a result, the Ministry advocates closer collaboration between HEls as a means of avoiding fragmentation and assuring higher quality.

Core funding for universities in Finland is spread across a series of different of areas. In $2015,8 \%$ of the funding was subject-specific, and covered subject areas that are particularly vulnerable, according to the Ministry's representative. This funding is intended to enhance specialisation and improve the quality of research and education. Which subjects receive this funding varies from year to year, depending on need. Finland does not have a specific support mechanism for small subjects. In addition to funds to meet specific needs, funding is allocated on a strategic basis. Strategic allocations accounted for $10 \%$ of funding for universities in 2015 , rising to $12 \%$ in 2017 . Strategic funding is provided to subjects of national importance, to strengthen new educational areas and to develop the educational structure.

A comprehensive university reform was introduced in 2009 to create stronger and more sustainable universities better able to meet the country's needs, raise the international profile of the Finnish universities and encourage international collaboration. The reform is designed to ensure that the universities are able to compete at international level by enhancing the quality, efficiency and relevance of research and education (Aarrevaara et al. 2009, Universities Finland 2010). The reform has led to a series of mergers in the HE sector. For example, the Helsinki School of Economics, Helsinki University of Technology and the University of Arts and Design merged to form the new Aalto University in 2010. The vision behind the reform was to reduce the number of universities from 20 to no more than 15 by 2020 (Aarrevaara et al. 2009; Universities Finland 2010). This goal has already been achieved - there are now only 15 universities in Finland (Centre for International Mobility 2016).

Certain universities play special roles in Finland. For example, Åbo Akademi University seeks to meet the needs of the Swedish-speaking population, and the majority of its programmes are in Swedish. Its remit includes providing HE programmes in Swedish and producing Swedish-speaking academics capable of meeting the nation's needs in the future.

A representative of the Ministry emphasised that Finland is in favour of closer collaboration on small and vulnerable subject areas throughout the Nordic Region. The Ministry considers Nordic co-operation extremely valuable, as it helps small subjects grow bigger and stronger, which enhances the quality of HEls in general.

Unlike Denmark, Finland does not have a specific scheme to support small subjects, but the government earmarks funds for subject areas that face particular challenges. Like Norway, Finland has introduced reforms that have led to mergers between a number of HEls. 


\subsubsection{Iceland}

Iceland does not operate with a definition of vulnerable subjects or have a separate funding scheme for them. The associate dean from the University of Iceland pointed out that, given its small size, many of the institution's programmes could be considered small or vulnerable. However, the priority - and the ring-fenced funding - is allocated to programmes considered to be of special national importance, such as Icelandic language and history. This does not necessarily mean that these subjects are vulnerable.

In general, the representative of the Icelandic Ministry of Education, Science and Culture's Department of Education and Science did not see vulnerable subject areas as a general problem. However, in the interview it emerged that many subject areas do not have enough academic staff, which makes the academic environment vulnerable and sensitive. Underfunding and low student intake can pose challenges to vulnerable study programmes, however, and the Ministry is considering how to involve vulnerable subjects in Nordic collaborations to a greater extent.

In summary, Iceland has not had to contend with as many problems associated with small and vulnerable subjects as the other Nordic countries, and the Ministry has not felt compelled to set up special funding and support schemes.

\subsubsection{The Faroe Islands, Greenland and Åland}

The Faroe Islands, Greenland and Åland do not operate with specific definitions of vulnerable humanities subjects. As relatively small societies, they have traditionally had many small subjects, despite the steady increase in student numbers in both Greenland and the Faroe Islands in recent years. The representative of the Faroese Ministry of Education, Research and Culture pointed out that what constitutes a small subject elsewhere may not be seen that way in the Faroe Islands. The University of the Faroe Islands, which merged with the Faroese School of Education and the Faroese School of Nursing in 2008, currently has about 800 students. Despite steadily increasing student numbers, this is a relatively small number compared to other Nordic universities. The representative of the Ministry pointed out that there has not been a need for a special policy on vulnerable subjects - and therefore no need for an official definition, either. On the other hand, the Faroe Islands have a political target of increasing the number of students up to 2024 , as well as plans to forge a sense of identity by concentrating the university on a single campus instead of having faculties scattered throughout Torshavn. The University of the Faroe Islands is state-funded, but the Ministry does not earmark specific funding for either small subjects or subjects of national interest. It is up to the University to decide how it wants to prioritise its funding.

Greenland considers it in the national interest to maintain two vulnerable humanities: theology and Greenlandic culture, literature and language. Both are kept alive due to the interest expressed in pursuing research in these areas. As Greenland is the only place where Greenlandic culture, literature and language is run as a programme, the decision has been taken to subsidise the programme despite low student intake and high operating costs. The University of Greenland has a limited 
number of students and a very limited number of lecturers and researchers. It collaborates with universities in Denmark and the other Nordic countries - especially Iceland, northern Norway and the Faroe Islands, for reasons of geographic proximity.

Åland has only one university: the Åland University of Applied Sciences. As it does not teach humanities, Åland is only mentioned in passing in this report.

\subsubsection{Summary}

The review above shows that there are major differences in the extent to which the Nordic countries focus on vulnerable subjects.

Norway has focused on the opportunities for working together on CSC, while Denmark has drawn up a small subjects scheme that allocates funding to programmes only offered by a single HEl. The ongoing structural reform in Finland seeks to concentrate resources in fewer HEls. Sweden, Iceland, the Faroe Islands, Greenland and Åland have not focused on CSC to the same extent. In Iceland, the Faroe Islands, Greenland and Åland, this is due to the fact that the majority of subjects taught there could be classified as small or vulnerable due to the limited size of their universities. Sweden has not focused on CSC to any great extent, nor have debates about small and vulnerable subjects figured as highly on the agenda as in the other countries. 


\section{Mapping vulnerable subjects}

The purpose of the quantitative mapping exercise was to provide an overview of the number and location of vulnerable subjects in the Nordic Region. Adding various key parameters to the overview provides additional insight into the similarities and differences between vulnerable subjects across both countries and institutions. Quantitative mapping is the only way of establishing a basis for comparison and interaction across vulnerable subjects. The knowledge generated was crucial to our ability to conduct an in-depth study and develop and strengthen collaboration across these vulnerable subjects. A quantitative survey is also the only way to identify precisely where efforts should be focused.

It proved very difficult to collect consistent data across the various countries. All of them publish some kind of statistical data on education and related subjects. However, these resources proved to be highly inadequate. The study identified a lack of key parameters, incomplete and in some cases outdated data, as well as data with very little detail. Incomplete data refers to data collated at faculty level rather than departmental or study programme level. To compound matters, the countries use different definitions, which make comparison difficult. The overall result is a body of data with numerous gaps.

We recommended that action be taken to upgrade and streamline data acquisition throughout the Nordic Region. For example, we recommend that Nordic guidelines are drawn up for the parameters to be reported, the level at which the reporting is to be done and the definitions to be used. This process of streamlining and upgrading would provide better information on which to base future evaluations. It would also provide opportunities for better, ongoing interaction between HEls.

The next section presents the results of our mapping exercise of vulnerable subjects in the Nordic Region based on the available data. It consists of a review of the data designed to provide a full overview of all of the parameters that help define what constitutes a vulnerable subject.

\subsection{Quantitative parameters}

The quantitative parameters were based on a study of the following criteria: student intake, dropout rates, number of academic staff and where subjects are taught. We then defined vulnerable subjects as follows: 
On EQF level 6, a vulnerable programme is defined as one with an intake of fewer than 20 students p.a. and a dropout rate of $30 \%$. On EQF level 7, a vulnerable programme is defined as one with an intake of fewer than 10 students p.a. and a dropout rate of $30 \%$.

The quantitative parameters are used to define vulnerable humanities subjects. Using this definition, a number of programmes were identified as vulnerable.

As mentioned, this assessment was based on the four quantitative criteria:

1. Number of students enrolled at bachelor and master's level.

2. Dropout rate (the number/proportion of students who fail to complete their study programme).

3. Number of full-time/part-time academic staff.

4. Number of locations at which small subjects are taught.

The four parameters were selected due to their relevance to the potential challenges faced by vulnerable subjects. As discussed above, student numbers and dropout rates form part of the definition. Intake is the key parameter, and forms the basis for the overall study. The dropout rate is interesting for two reasons. Firstly, a high dropout rate leads to a significant reduction in the number of students during the course of the study programme. This presents a challenge to the academic environment in much the same way as low student intake. A high dropout rate may also be an indicator of underlying problems. A low number of academic staff is a potential problem if it makes it difficult to maintain expertise in all of the areas covered by the programme. The number of HEIS that teach the subject is also a relevant parameter. For example, if a subject is taught on several different campuses or at a few different HEls that are geographically far from each other, it may lead to insufficient contact between academics or an inappropriate spread of competencies and teaching.

The individual parameters are examined in greater depth below.

\subsubsection{Overview of vulnerable subjects with potential for work on CSC}

This section provides an overview of study programmes categorised as vulnerable under the definition above. Table 3 lists vulnerable subjects taught in at least three of the Nordic countries. This means that subjects taught in two countries (for example) are not included, even though they might be described as vulnerable and ideal candidates for work on CSC.

The data has been sourced from the national statistics offices or from the national education ministries. The data sources used in this chapter are listed in Appendix 2. 
Table 3: All vulnerable subjects taught in three or more countries

\begin{tabular}{|c|c|c|}
\hline /Country & HEI & Subject \\
\hline \multicolumn{3}{|l|}{ History, EQF 6} \\
\hline Norway & University of Stavanger & History in Depth \\
\hline Faroe Islands & University of the Faroe Islands & History and Social Science \\
\hline Denmark & University of Southern Denmark & Bachelor in History \\
\hline Norway & Nord University & Bachelor in History \\
\hline Finland & Åbo Akademi University & Master's in History \\
\hline Norway & Nord University & One-year History programme \\
\hline \multicolumn{3}{|c|}{ History, EQF 7} \\
\hline Faroe Islands & University of the Faroe Islands & History and Social Science \\
\hline Denmark & University of Southern Denmark & Two-year master's in History \\
\hline Norway & University of Troms $\varnothing$ - the Arctic University of Norway & A \\
\hline \multicolumn{3}{|c|}{ Archaeology, EQF 7} \\
\hline Finland & University of Helsinki & Master's in Archaeology \\
\hline Norway & University of Troms $\varnothing$ - the Arctic University of Norway & Master's in Archaeology \\
\hline Denmark & $\mathrm{KU}$ & Master's in Classical Archaeology \\
\hline Denmark & KU & Near Eastern Archaeology \\
\hline Sweden & Stockholm University & Master's in Archaeology \\
\hline Norway & University of Bergen & Master's in Archaeology \\
\hline Denmark & $\mathrm{AU}$ & Master's in Classical Archaeology \\
\hline Denmark & $\mathrm{AU}$ & Medieval Archaeology \\
\hline Norway & Norwegian University of Science and Technology & Master's in Archaeology \\
\hline \multicolumn{3}{|c|}{ Archaeology, EQF 6} \\
\hline Finland & University of Helsinki & Master's in Archaeology \\
\hline Finland & Åbo Akademi University & Master's in Archaeology \\
\hline Denmark & KU & Near Eastern Archaeology \\
\hline Denmark & $\mathrm{KU}$ & Bachelor in Classical Archaeology \\
\hline Norway & University of Troms $\varnothing$ - the Arctic University of Norway & Bachelor in Archaeology \\
\hline \multicolumn{3}{|l|}{ Italian, EQF 6} \\
\hline Finland & Åbo Akademi University & Italian Language \\
\hline Norway & University of Bergen & Bachelor in Italian \\
\hline Finland & University of Helsinki & Italian Language \\
\hline Denmark & $\mathrm{AU}$ & Bachelor in Italian \\
\hline Sweden & Stockholm University & Italian Language and Translation \\
\hline \multicolumn{3}{|l|}{ French, EQF 7} \\
\hline Finland & University of Helsinki & Master's in French \\
\hline Finland & Åbo Akademi University & Master's in French \\
\hline Denmark & $\mathrm{AU}$ & French, two-year master's in Business Language \\
\hline Denmark & Roskilde University & Two-year master's in French Studies \\
\hline Denmark & SDU & $\begin{array}{l}\text { French, two-year master's in Business } \\
\text { Administration and Languages }\end{array}$ \\
\hline Norway & Norwegian University of Science and Technology & Master's in French \\
\hline Norway & University of Bergen & Master's in French \\
\hline Denmark & $\mathrm{AU}$ & French, two-year master's in Business Language \\
\hline \multicolumn{3}{|l|}{ French, EQF 6} \\
\hline Norway & University of Agder & Bachelor in French \\
\hline Norway & University of Bergen & One-year programme in French \\
\hline Finland & Åbo Akademi University & Master's in French Language \\
\hline Finland & University of Tampere & Master's in French Language \\
\hline Norway & University of Bergen & Bachelor in French \\
\hline Denmark & $\mathrm{AU}$ & Bachelor in French Studies \\
\hline Finland & University of Jyväskylä & Master's in French Language \\
\hline Finland & University of Helsinki & Master's in French Language \\
\hline
\end{tabular}




\begin{tabular}{|c|c|c|}
\hline ICountry & HEI & Subject \\
\hline \multicolumn{3}{|c|}{ English EQF 7} \\
\hline Finland & University of Jyväskylä & Master's in English Language \\
\hline Finland & University of Tampere & Master's in English Language \\
\hline Finland & University of Oulu & Master's in English Language \\
\hline Finland & University of Vaasa & Master's in English Language \\
\hline Denmark & $A U$ & English, two-year master's in Business Language \\
\hline Denmark & SDU & Two-year master's in English \\
\hline Finland & University of Eastern Finland & Master's in English Language \\
\hline Norway & Norwegian University of Science and Technology & Master's in English \\
\hline Denmark & Roskilde University & Two-year master's in English \\
\hline \multicolumn{3}{|c|}{ Musicology EQF 7} \\
\hline Sweden & Uppsala University & Musicology \\
\hline Finland & University of Tampere & Master's in Musicology and Music Pedagogy \\
\hline Finland & Åbo Akademi University & Master's in Musicology and Music Pedagogy \\
\hline Norway & Norwegian Academy of Music & Master's in Performing Music Technology \\
\hline Norway & Norwegian Academy of Music & Master's in Applied Musical Theory \\
\hline Finland & University of Helsinki & Master's in Musicology and Music Pedagogy \\
\hline Norway & Norwegian University of Science and Technology & Master's in Music Technology \\
\hline Norway & University of Bergen & Master's in Music Performance or Composition \\
\hline Norway & University of Troms $\varnothing$ - the Arctic University of Norway & Master's in Musical Performance \\
\hline Denmark & Aalborg University (AAU) & Two-year master's in Music/Musicology \\
\hline \multicolumn{3}{|c|}{ Philosophy, EQF 6} \\
\hline Denmark & SDU & Bachelor of Philosophy \\
\hline Finland & Åbo Akademi University & Master's in Philosophy (Humanities) \\
\hline Norway & University of Bergen & One-year Philosophy programme \\
\hline Finland & University of Helsinki & Master's of Philosophy (lower) \\
\hline Finland & University of Tampere & Master's in Philosophy (Humanities) \\
\hline Finland & University of Helsinki & Master's in Philosophy (Humanities) \\
\hline Finland & University of Jyväskylä & Master's in Philosophy (lower) Social Sciences \\
\hline Finland & Åbo Akademi University & Master's of Philosophy (lower) \\
\hline Norway & University of Troms $\varnothing$ - the Arctic University of Norway & Bachelor of Philosophy \\
\hline
\end{tabular}

Source: DAMVAD Analytics 2016.

\subsubsection{Student intake}

As far as possible, data was acquired for 2014. The threshold criteria for vulnerable subjects was set at an intake of 20 students or fewer p.a. to bachelor programmes corresponding to EQF level 6 , and 10 or fewer to master's programmes corresponding to EQF level 7. The data covers all HEls running programmes on these EQF levels. The table below shows the number of humanities programmes at bachelor and master's level where maximum student intake has been set at 20 and 10 respectively.

Table 4: Number of study programmes

\begin{tabular}{l|r|r|r|}
\hline Country & $\begin{array}{r}\text { Number of bachelor programmes } \\
\text { with student intake of } \mathbf{2 0}\end{array}$ & $\begin{array}{r}\text { Number of master's programmes } \\
\text { with student intake of 10 }\end{array}$ & Comments on the data \\
\hline Denmark & 78 & 78 \\
Norway & 171 & 86 \\
Sweden & 19 & 36 & \\
Finland & 52 & 1 & No data* \\
Faroe Islands & 1 & No data \\
Iceland & & & 58 \\
Greenland & & & \\
\hline
\end{tabular}

Note: * Iceland does not compile intake data at programme level, only the number of students enrolled.

Source: DAMVAD Analytics 2016. 
The table shows that Norway has the highest number of vulnerable subjects. One reason for this is that Norway has a very high number of HEls. However, Denmark, Sweden and Finland also have considerable numbers of vulnerable subjects. In the Faroe Islands, two programmes have been identified as vulnerable, but it has not been possible to obtain data that sheds light on the issue in Iceland and Greenland.

Student intake into HEls is one quantitative indicator of vulnerability. Collating data on student intake on the various study programmes within a given academic environment indicates the size of the subject and says something about student recruitment.

The Nordic countries do not have a definition of vulnerable academic subject areas based on student intake. Denmark and Norway do, however, use an indicative quantitative threshold of 20 students for small subjects. In Denmark, funding for vulnerable subjects is also partly linked to intake, which makes it an appropriate factor to include in any definition of vulnerability.

Based on our literature review and interviews, we think that it would be appropriate to set an upper limit on the definition of small subjects of 20 students at bachelor level (EOF 6) and 10 at master's level (EQF 7 ) because they lack critical mass, especially when the potential dropout rate is taken into account. Low student intake makes it difficult to maintain high academic and research standards with sufficient depth and breadth in the subjects and study courses offered, and to internationalise research and compete on a global level.

One of the difficulties involved in setting a quantitative limit on student intake is that it may incentivise HEls to reduce student numbers. Any scheme based solely on the size of intake risks creating an incentive culture that counteracts the ambition of developing robust and sustainable programmes. For this reason, Denmark has chosen not to base its national scheme for small subjects solely on student intake, but also on programmes only taught at a single HEl. Under the Danish small subjects scheme, funding is also linked to the academic environment, rather than to specific study programmes, because small programmes may already be vulnerable. This means that should one of these programmes shut down, the funding is not lost but can still be invested in the general academic environment. Student intake alone does not, therefore, constitute a sufficient basis on which to define a small subject, but it helps outline the programme's size and indicate the challenges faced, e.g. with recruitment. Below, we look at these programmes on the basis of the four parameters. The data sources are listed in Appendix 2.

Figure 2 illustrates the distribution of students. Vulnerable study programmes are divided up according to the number of students that HEls enrolled in 2014. 
Figure 2: Number enrolled/number of programmes

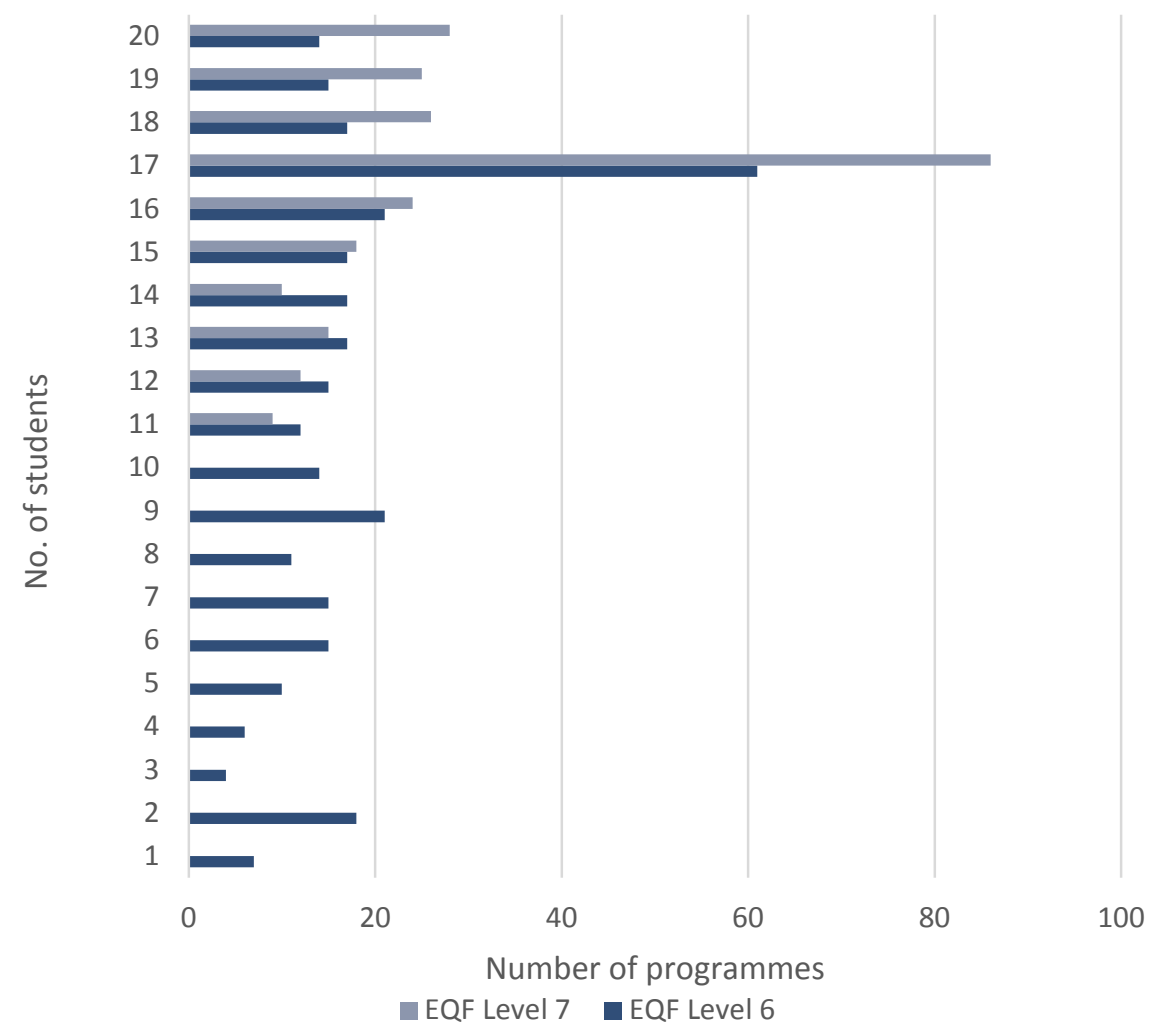

Source: DAMVAD Analytics 2016, $n=580$.

In the figure, the study programmes are broken down by student numbers and academic level. The purple bars show master's programmes (EQF 7), the blue ones show bachelor programmes (EQF 6). Note that only master's programmes with up to 10 students are included. Above this level, they drop out of the study, as per the vulnerability definition.

Note also that there appears to be a fairly even distribution of the number of students enrolled on the vulnerable programmes. In 2014, an average of 8.7 students enrolled on bachelor programmes with the threshold value set at 20 , and 4.4 on master's programmes with the threshold set at 10.

A very large number of both bachelor and master's programmes have an intake of just four students. There is no obvious explanation of why so many programmes have precisely four students, but a more detailed analysis shows that it is primarily Denmark that accounts for this phenomenon. ${ }^{11}$

${ }^{11}$ The Danish intake data is discretionary and programmes with fewer than four students have not been included. 
In 2014, 2,856 students enrolled on vulnerable bachelor programmes, and 1,116 on vulnerable master's programmes, making a total intake of 3,972 students on vulnerable subjects.

The map below shows how a vulnerable subject can be represented with very few students, spread across a relatively large number of institutions. This suggests that there is potential for collaboration on small subjects. The subject in this example is Italian at master's level (EOF 7).

\section{Figure 3: Italian at Nordic universities}

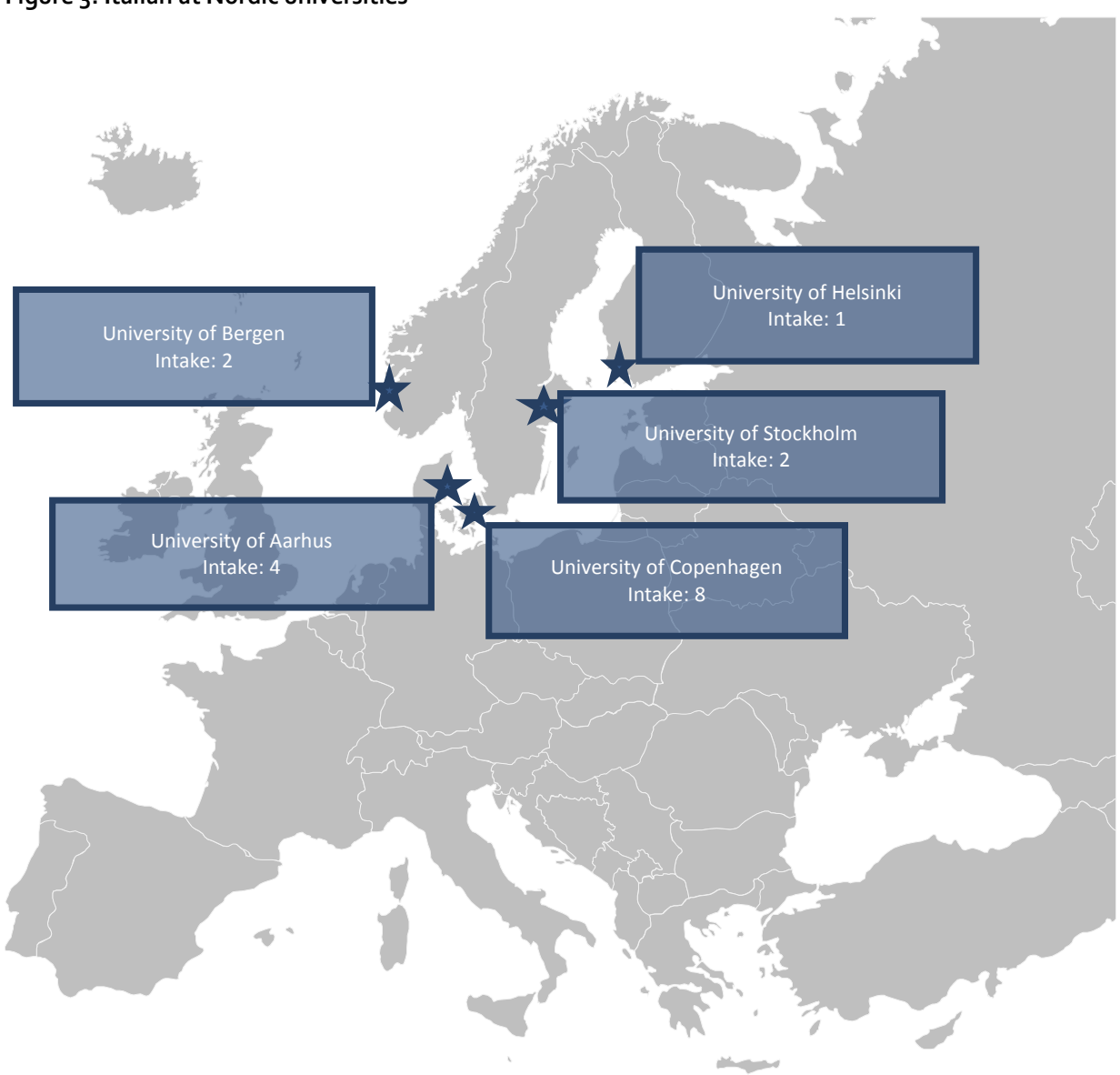

Source: DAMVAD Analytics 2016, $\mathrm{n}=580$.

\subsubsection{Dropout rates}

A high dropout rate can result in small, fragile study environments, especially on master's programmes. High dropout rates are a challenge to vulnerable subject areas because the students have difficulty planning careers or fear that the programme will be closed or merged into other, larger programmes/subject areas (Danish Accreditation Institution and DAMVAD (2014)).

There is no fixed upper limit for the point at which dropout becomes critical, but some Danish and Norwegian HEls operate with a limit of $30 \%$. However, in many cases 
this limit is relative, as the dropout rate at bachelor level (EQF 6) may well be higher without it being problematic for the subject per se. On the other hand, a dropout rate of less than $30 \%$ may be extremely critical for a master's (EQF 7) programme. One challenge associated with setting an upper limit for dropout rates as part of the vulnerability definition is that it is not necessarily as much of a problem for every country, and may be subject-specific.

Dropout data is based on the cohort of students who should have completed their study programmes in 2014. As noted above, the available data on this parameter is incomplete, and allowances have to be made for this in our conclusions. It was only possible to obtain specific dropout data for Denmark. The data for Sweden and Norway has been estimated based on the number of completed programmes. See Appendix 2 for details of the data. This report recommends that the data for this parameter be improved, as it is crucial to the ability to develop the programmes.

In Figure 4, vulnerable subjects are broken down by dropout rate. Note that most of them have high rates. The average for the programmes for which rates are available is $28.2 \%$. By comparison, the average dropout rate for all Danish bachelor programmes (vulnerable and non-vulnerable) was $17.3 \%$.

Figure 4: Dropout rates

Share of vulnerable subjects

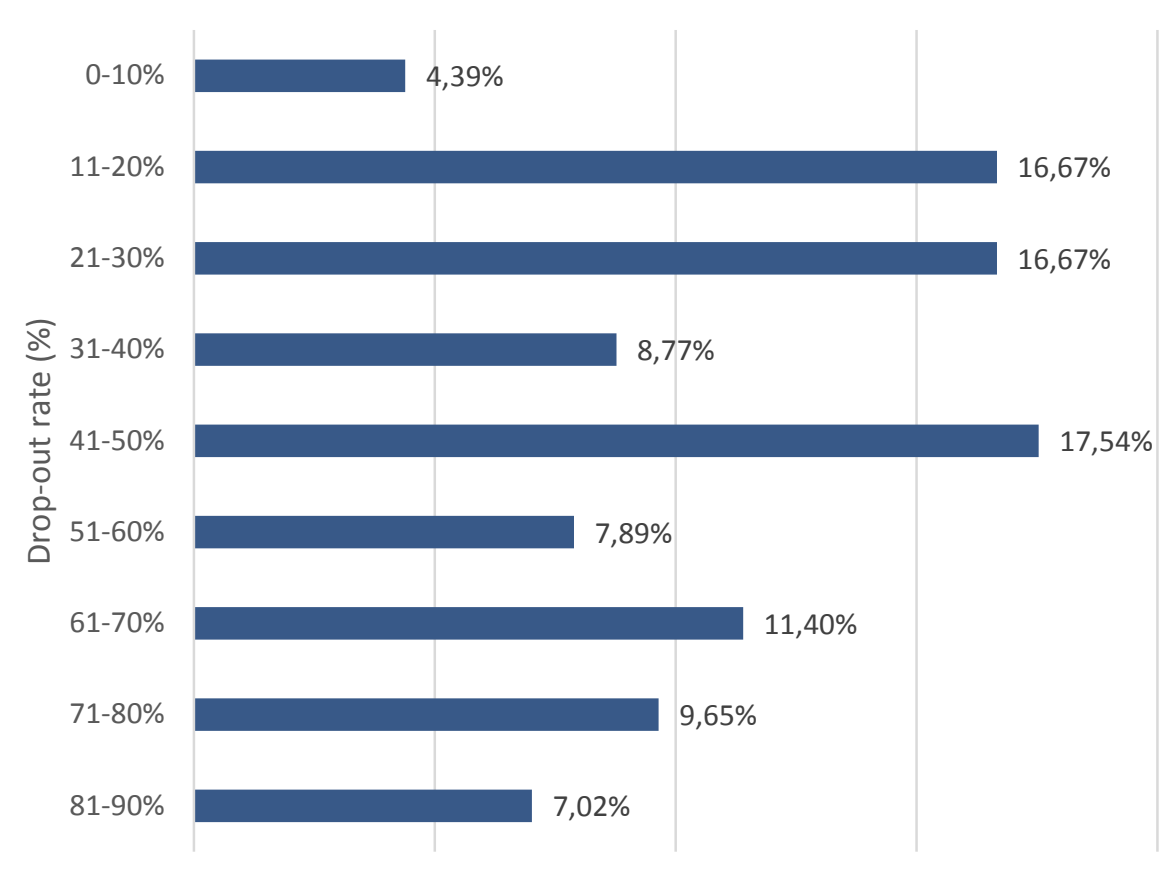

Source: DAMVAD Analytics 2016, $n=114$. The dropout rate is defined as the proportion of the annual cohort scheduled to complete their programme in 2014 but no longer registered on it. 
The figure also reveals a fairly large spread in dropout rates: From 2\% (Master's in Religion, Ethics and Society - University of Agder, Norway) to 92\% (Art and Handicrafts - University of Stavanger, Norway). This makes it necessary to look at the individual programmes to evaluate whether the dropout rate constitutes a problem.

\subsubsection{Academic staff}

It has not been possible to acquire data for full-time (VIP) and part-time academic staff (DVIP) at programme level for all of the Nordic countries. In Denmark and Norway, for example, these numbers are only compiled at department level. As a result, Nordic comparisons across HEls and borders are only possible at department level.

It is clear from the interviews with the Nordic ministries that academic staff numbers are not taken into account in discussions on how best to define vulnerability. However, this does not mean that academic staff numbers do not play a significant role in the way that countries relate to the problem of vulnerable subjects. One reason for not including academic staff numbers in the definition is that it is entirely possible for a vulnerable subject to have a suitable number of academic staff. A definition based solely on numbers of academic staff would therefore risk excluding subjects that are vulnerable in areas other than staffing levels. An additional complication is that teaching staff at most HEls teach on multiple subjects/programmes, and they would have to be counted on all of them.

Given the above, we believe that student intake and dropout rates provide more accurate quantitative parameters for defining vulnerable humanities subjects. However, even though academic staff numbers are not included as part of the definition, the parameter still provides information on the size of the academic environment of which a study programme is part. It has also been difficult to acquire consistent data on the numbers of full-time and part-time academic staff. For example, it has not been possible to directly correlate numbers of full-time and part-time academic staff with individual study programmes. This made it impossible to provide an overall picture of academic staff numbers in vulnerable subject areas. For the same reason, it was impossible to incorporate this parameter into the definition. This is something else that can be addressed in future upgrading of the data sources.

\subsubsection{Geographical spread of subjects}

The geographical distances between HEls can be quite considerable in some of the Nordic countries, especially in Norway, Sweden and Finland. Even if a programme is run by several different HEls in the country, individual students (not to mention companies where graduates will work or institutions where they will continue their studies) may still be many hundreds of kilometres away from the nearest HEI that teaches the subject. Countries where the population is spread across great distances need a good balance between decentralisation, the development of strong academic environments and good use of resources. 
Some subjects would traditionally be considered large when measured in terms of intake, but may be counted as small programmes because they are taught on many different campuses at different HEls in the countries concerned. This can lead to overlap between the subject areas covered by multiple institutions. In a similar vein, small subject areas may be more vulnerable to fragmentation and dispersal. It would therefore be a good idea to incorporate thinking about work on CSC and the principles behind it into national initiatives as well as purely Nordic ones. This would often be an easier solution than cross-border collaboration.

In Sweden, 17 different HEls cover the humanities. The table below shows the number of HEls at which humanities subjects were offered to the summer 2015 student intake. The programmes were categorised manually because the data sources do not provide this information in digital form.

Table 5: Geographical spread, Sweden

African Studies

Archaeology

Asian Studies

Baltic Languages

Dance Studies

English

Aesthetics

Ethnology

European Studies

Film Studies

Philosophy

Gender Studies

History

History of Ideas

Journalism

Classical Studies

Communication

Art History

Culture Studies

Conservation

Latin American Studies

Literature

Middle Eastern Studies

Musicology

Nordic Studies and Languages

Pedagogy

Religion

Rhetoric

Romance Languages

Slavic Languages

Linguistics

Theatre Studies

Theology

German

Source: DAMVAD Analytics 2016.

The table shows that, in some categories of the humanities, up to eight different HEls run study programmes covering the same academic area. Some of the small language subjects are also taught at multiple institutions, e.g. German is available at five different HEls. 
In Norway, 39 different HEls teach humanities. The table below shows how they are categorised by the data sources.

Table 6: Geographical spread, Norway

\section{Norway}

\section{Librarianship}

Health Sciences

Industrial Design

Master's in Teacher Training

Practical Pedagogy

Journalism/Photography

Sign Language Interpretation

Fine Arts

Visual Arts

Performing Arts

Design

Pedagogy

Theology

Other

Examen philosophicum (Introduction to Philosophy)

Social Sciences

Musical Performance

History/Philosophy*

Note: * Neither the Norwegian Centre for Research Data (NSD) nor the Database for Statistics on Higher Education (DBH) breaks down the data any further for History/Philosophy.

The data also clearly shows that programmes in some of the humanities are spread around the country. This is a natural consequence of the large number of HEls in Norway. This poses challenges in relation to the problems outlined above.

Finland only operates with very general categorisation for the spread of subjects. As shown in Table 7), the "humanities" category can be very broad. This makes it difficult to determine whether geographical spread is actually a real problem in Finland.

Table 7: Geographical spread, Finland

Art and Design

Education:

Fine Arts

Music

Humanities

Theatre and Dance

Theology

Source: DAMVAD Analytics 2016.

In Denmark, the humanities are taught at a maximum of five HEls. The table below shows the spread for the summer 2015 intake. As the table shows, Denmark has relatively few subjects taught only by one or two HEls: the majority of the subjects classified as vulnerable are taught by several different ones. Despite the limited size of the country, how programmes are spread across institutions in Denmark is still relevant, and an obvious target for work on CSC at national level. 
Archaeology

Danish-Nordic Language and Literature

Digital Design and Interaction Design

Business Languages, combined

Business Languages, master's

Ethnology

Film, Theatre and Music Studies

Philosophy

History

History of Ideas and Science

Information Science

Journalism and Rhetoric

Classical Languages and Philology

Communications

Linguistics

Comparative Literature

Middle Eastern languages

Musical Therapy

Ancient languages

Experiential Design

Religion and Religious Studies

Romance Languages

Slavic, East European and Balkan

South-east Asian Languages

Theology

West Germanic

East Asian Languages

Other language programmes

Source: DAMVAD Analytics 2016.

\subsection{Summary}

As shown above, the available data makes it possible to outline general characteristics of vulnerable subjects based on student intake and dropout rates for the different study programmes. However, it is not possible to correlate with other parameters throughout the Region. The overall impression is of an area in which there is a dearth of information in terms of purely quantitative parameters. The data provides a basis for selecting the programmes included in the study, but it does not allow for the inclusion of additional knowledge via other parameters. This severely limits the analytical insights achievable from the quantitative data available. If more work is to be done on this element (the qualitative parameters) in future analyses, it will therefore be necessary to work systematically on upgrading and streamlining the available data. 


\section{Strengths of and obstacles to Nordic work on CSC}

This chapter presents existing national and Nordic collaboration identified by desk research and via interviews with education ministries, deans, associate deans, lecturers, heads of study and heads of department. It also presents the strengths of and obstacles to Nordic co-operation, based on the available data.

\subsection{Characteristics of vulnerable subjects across the Nordic countries}

Several studies have been conducted of the existing problems faced by small subjects, and these have identified a number of challenges that recur in all of the Nordic countries. Several of these challenges were also frequently highlighted in the interviews. The challenges suggest a need for closer Nordic collaboration on aspects like achieving critical mass, improving research and study environments, and enhancing the range and variety of subjects and courses. We have divided the challenges into themes.

\subsubsection{Critical mass}

Several studies (Danish Accreditation Institution \& DAMVAD, 2014; Ad hoc group for work on CSC, 2013; Stjernø Committee, 2008; Norwegian Research Council, 2016; University of Gothenburg, 2013; Norwegian Ministry of Education and Research, 2015a; NIFU-Nordic Institute for Studies in Innovation, 2012) show that it is difficult for small and vulnerable subject areas to recruit qualified lecturers, researchers and students. This is particularly significant in countries with a wide geographical spread between programmes. Demographic changes and urbanisation also affect recruitment. The conclusions indicate that it may be difficult to guarantee high academic and research standards in vulnerable subjects. Many vulnerable subject areas also find it difficult to achieve critical mass among lecturers, researchers and students. This was also brought up in the interviews (Department of Musicology, Uppsala University; Director of Studies in French, Stockholm University; Professor of China Studies, Stockholm University).

Some subject areas use part-time academic staff and external lecturers, because it is impossible to recruit and retain enough staff. This makes them particularly vulnerable to staffing changes (ACE Denmark \& DAMVAD, 2011; the Danish Accreditation Institution \& DAMVAD, 2014; University of Gothenburg, 2013). Some of the small subject areas also face challenges with quality assurance, in particular in relation to 
evaluation methods, dropout and graduate surveys, because they lack the resources for these processes (ACE Denmark \& DAMVAD, 2011; the Danish Accreditation Institution \& DAMVAD 2014).

\subsubsection{Finance and resources}

Running small study programmes can be an expensive business. Often, it is the case that the big programmes finance the small ones. Small subjects spend many hours per student on administration and teaching, which weakens the research basis of both the teaching and the programme as a whole (Danish Accreditation Institution \& DAMVAD, 2014; Ad hoc group for work on CSC, 2013; Associate Professor, French, Aarhus University). This is particularly significant for small HEls in sparsely populated areas, which do not enjoy the same economies of scale as larger institutions. The low number of lecturers and minimum enrolment limits also mean that it can be difficult to offer the same variety and volume in the number of courses as larger programmes are able to offer (Danish Accreditation Institution \& DAMVAD, 2014; Stjernø Committee, 2008; Norwegian Ministry of Education and Research, 2015a).

\subsubsection{Study environment}

Small and fragile study environments make it difficult to retain students and lead to high dropout rates, especially on master's programmes. High dropout rates are a challenge to vulnerable subject areas, because the students have difficulty planning careers or fear that the programme will be closed or merged into other, larger programmes/subject areas (Danish Accreditation Institution \& DAMVAD 2014; Lid 2014). Small and vulnerable programmes also usually provide few hours of teaching, which makes self-study important and places heavy demands on the students' ability to structure their studies. On the other hand, the closeness between students and researchers in small academic environments can be an advantage, as it leads to more personal dialogue and direct interaction. It can also bring the students closer to the research that is conducted locally (ACE Denmark \& DAMVAD, 2011; Danish Accreditation Institution \& DAMVAD, 2014).

\subsubsection{Internationalisation}

The demand for internationalisation can also be a problem for small and vulnerable subject areas, which may find it difficult to raise their profile at international level (Danish Accreditation Institution \& DAMVAD, 2014; Ad hoc CSC group, 2013; Stjernø Committee, 2008; Norwegian Ministry of Education and Research, 2015a; Nordic Institute for Studies in Innovation, 2012).

Given the characteristics and challenges shared by small subjects throughout the Nordic Region, there may be many advantages to collaboration and specialisation at both Nordic and national level. The following section highlights some of the strengths of Nordic co-operation. 


\subsection{Strengths of Nordic co-operation}

The previous section identified a range of characteristics shared by vulnerable subjects throughout the Nordic Region. The interviews with deans and associate deans highlighted the potential and strengths of Nordic collaboration as a means of addressing these shared characteristics. The points raised are also supported by past experience and studies, as shown below.

\subsubsection{Greater breadth and depth}

One of the ways in which work on CSC can strengthen vulnerable subjects is by providing access to a larger pool of qualified lecturers, researchers and students (University of Gothenburg, 2013; Norwegian Ministry of Education and Research, 2015a; Ad hoc CSC group, 2013; Danish Accreditation Institution \& DAMVAD, 2014; Stjernø Committee, 2008; Head of Department of Musicology, Uppsala University; Head of studies in Classical Philology, University of Oslo; Professor of China Studies, Stockholm University). Exchange programmes provide one avenue for institutions to attract external lecturers and make their study environments less vulnerable to staffing changes (University of Gothenburg, 2013; Danish Accreditation Institution \& DAMVAD, 2014). A larger pool of lecturers and students also facilitates greater variation and higher numbers of courses (University of Gothenburg, 2013; Danish Accreditation Institution \& DAMVAD, 2014; Norwegian Ministry of Education and Research, 2015a; Ad hoc CSC group, 2013; Stjernø Committee; Department of Comparative Literature, Norwegian University of Science and Technology; Head of Philosophy, University of Southern Denmark; Head of East European Studies, University of Lund). Various committees and reports have emphasised this point.

\subsubsection{Development}

Collaboration allows vulnerable subjects to continue to develop in new areas and keep abreast of new knowledge in their field. This boosts their capacity to expand the areas in which they conduct research and stimulates new approaches to the subject (Head of Department of Comparative Literature, Norwegian University of Science and Technology; Head of Classical Philology Studies, University of Oslo). Collaboration also provides institutions with the opportunity to retain academic competencies that are beneficial to research. Collaboration brings together strengths and expertise from different institutions, while ensuring that competencies are not all concentrated in a single HEl. This can help enhance the quality of the study programmes and provide students with access to all of the latest knowledge in their field (Professor of China Studies, Stockholm University). These points are highlighted by the following: Stjernø Committee (2008); Ad hoc CSC group (2013); Danish Accreditation Institution \& DAMVAD (2014); Norwegian Ministry of Education and Research (2015a); and NIFU (2012). 


\subsubsection{Economies of scale}

Small subjects spend a greater proportion of their time on administration and teaching, which weakens the research basis of both the programme and the teaching. Concentrating vulnerable study subjects reduces administration costs (Associate Professor of French, University of Aarhus). Several studies (Gaia Consulting, 2015; Stjernø Committee, 2008) also show that pooling resources through cross-border collaboration has financial benefits for both research and teaching. However, some interviewees pointed out that collaboration can be expensive if getting it up and running involves a lot of administrative work (Head of Studies, University of Oslo).

\subsubsection{Nordic networks}

Work on CSC creates networks that benefit teaching and academic environments via the exchange of knowledge and research (Head of Studies in Classical Philology, University of Oslo; Associate Professor of Viking and Norse Studies, Aarhus University). In this context, the Associate Professor of Musicology at the Norwegian Academy of Music noted that the main strength of work on CSC is that large HEls are able to share knowledge with smaller ones through academic networks, and that this helps to develop the smaller HEls and enhances the quality and standards of the study programmes. A study conducted for NordForsk (Gaia Consulting 2015) also showed that knowledge networks have positive effects in terms of establishing personal contacts and engendering trust between HEls.

\subsubsection{Increased internationalisation}

Work on CSC can help raise the international profiles of vulnerable subjects and maintain academic competencies that are beneficial to research in the subject. The Head of Comparative Literary Studies at the Norwegian University of Science and Technology emphasised that work on CSC can help foster internationalisation by enabling students to travel around the Nordic countries. Work on CSC can also help to improve international visibility (Dean of Faculty of Arts, University of Helsinki). Several studies have shown that collaboration can help improve international competitiveness (Gaia Consulting, 2015; Stjernø Committee, 2008; Ad hoc CSC group, 2013; Norwegian Ministry of Education and Research, 2015a).

\subsubsection{Nordic added value}

The Nordic countries have a lot in common. They have similar values, share an educational culture and face a number of the same challenges with regard to vulnerable subjects. It makes sense for the Nordic countries to work together to strengthen Nordic competencies and competitiveness in vulnerable humanities subjects. The strong sense of affinity between the countries and the work done on CSC can help to preserve Nordic languages and cultures, and enhance competencies (Head of Comparative Literary 
Studies, the Norwegian University of Science and Technology). Nordic co-operation generates synergies that are beyond the reach of national measures.

\subsection{Challenges associated with collaboration}

A number of parameters are important when it comes to starting up work on CSC. Based on the interviews with deans and associate deans, we have identified a series of challenges that are particularly relevant to vulnerable subjects. Collaboration involves a level of commitment that puts limits on flexibility, since the department concerned must commit to running the programme no matter how few students sign up for it. This can make it more attractive for small subject areas to focus on expanding their subject area rather than entering into binding collaboration, especially if part of the commitment involves giving something up. The Associate Dean for Education in the Humanities at the University of Copenhagen also stressed that it can be difficult to get work on CSC off of the ground in vulnerable subjects because it can be difficult and expensive to mobilise small numbers of students.

Work on CSC is further complicated by the self-interest of the HEls. Several interviewees (including the head of studies for Philosophy at the University of Southern Denmark) pointed out that lecturers - both for competitive reasons and due to workrelated pressures - are often inclined to prioritise their own academic networks within the HEl concerned rather than Nordic partnerships. Several heads of study, heads of departments and deans said that the priority at the moment is the recruitment and retention of students, and that collaboration agreements are not high on the agenda.

In the following section, we look at the general challenges facing work on CSC that emerged from the interviews and the review of past experiences.

\subsubsection{Different national frameworks}

A number of issues make Nordic co-operation difficult. First of all, the countries have their own national frameworks. This means that, for example, that they have different regulations for accreditation (Norden, 2015; Gaia Consulting, 2015; Danish Accreditation Institution \& DAMVAD, 2014; Ad hoc CSC group, 2013). Closer collaboration between the countries would therefore mean that the national accreditation requirements would have to be aligned and relaxed to stop them acting as a barrier to working together. The accreditation process for new study programmes is demanding in terms of resources, and often puts a dampener on plans to develop new programmes along with other HEls or simply continuing programmes that have already been accredited (Danish Accreditation Institution \& DAMVAD, 2014).

Some interviewees emphasised that national accreditation and quality-assurance systems can serve as an obstacle to Nordic co-operation. The Head of Studies and Head of the Department of Communication and Culture at Aarhus University pointed out that the administration involved in establishing new joint programmes, along with the complex rules in the area, act as a barrier to work on CSC. The Head of Comparative 
Literary Studies at the Norwegian University of Science and Technology pointed out that the administration is difficult and that CSC work is time-consuming. The administrative officer involved has to know all about the way in which studies are structured, curricula, etc. at the other HEls. This is highly demanding, and according to the head of department, it can take up what corresponds to somewhere between a part-time and a full-time post. The Associate Dean of Education at the University of Tromsø also mentioned that the Norwegian quality-assurance system presents a number of challenges to collaboration with other Nordic HEls. Several associate deans stated that better administrative frameworks are needed for collaboration to succeed because the initial setup is time-consuming, and requires a lot of planning and administrative resources.

Institution-specific regulations also make international collaboration difficult (DAMVAD 2014: interview with deans/associate deans):

- Differences in term/semester structure (academic calendar).

- Differences in ECTS weighting of major assignments and whole programmes.

- Exam types (e.g. with or without external examiner).

- Admission procedures and timescales.

- Grading scales.

- Internal procedures for quality assurance.

Different HEls may also have different ministerial orders, academic cultures, teaching traditions and languages. According to the Associate Dean of the University of Aarhus, this is just as much the case within the Nordic Region as elsewhere. The Associate Dean of the University of Tromsø emphasised that the more concrete the collaboration, the more difficult it is, because each department has its own way of teaching the subject. These practical barriers also apply to research collaborations, where differences in traditions and ways of working, coordination of activities, research focus and interests were all mentioned as challenges (Gaia Consulting, 2015).

Despite the different education systems, the Associate Dean of Education at the University of Oslo believes that most of the practical problems can be solved with good relations and well-motivated staff. Collaboration on student-exchange programmes rarely leads to practical difficulties sending students to summer schools or on exchange visits. Setting up joint degrees is more complicated, however, because the structure has to be approved by all of the parties involved. This was confirmed by an assistant professor at the University of Copenhagen, who stressed that a committed lecturer can often be the key to making informal collaboration work. One example of this is the collaboration on Eastern European studies between the University of Copenhagen and Lund University (see the case study in Chapter 6). As well as different curricula and teaching traditions, differences in language can also present challenges. To a great extent, successful collaboration requires programmes being run in English (Associate Dean, University of Helsinki; Dean of Language and Literature, University of the Faroe Islands). However, it appears that the biggest challenge facing the Nordic joint degree 
programmes is the changes that have taken place in relation to students from outside the European Economic Area. Tuition fees have increased significantly because of the changes, and the number of applicants has fallen. ${ }^{12}$

\subsubsection{Lack of funding}

The different Nordic countries have different funding arrangements for higher education. Specifically, there are differences in the way funding is earmarked for teaching and research, and there are differences in the mix of core funding, performance-based funding and competitive funding. These differences can hinder closer collaboration in the short term if institutions are funded according to different parameters, because it means that they have different objectives and strategies that are incompatible with work on CSC if collaboration requires adjustment. Contracts, agreements or an alignment of systems are all needed before the HEls feel motivated and see the added value in the collaboration.

Joint programmes are relatively expensive to develop and implement, due to high start-up costs (DAMVAD 2014, 2013). Not only do they place great demands on resources in the beginning - in the form of the time and money used to "buy" lecturers and administrative staff to develop the process - but joint programmes also incur a range of operating costs, as they are more expensive than traditional exchange agreements. The HEls involved need to coordinate and organise the teaching, syllabus, curriculum, learning objectives, etc., which is a far more demanding process in terms of resources due to the different national legal and regulatory frameworks than it would be if the programme were only based on a single country.

At the moment, no funding is earmarked for the development of joint programmes in the individual Nordic countries. HEls must either earmark money from their overall funding or apply for other funds, for example EU funding if the collaboration involves EU member states. However, the Nordic Master Programme does provide funding for the development phase of joint programmes. As well as the financial challenges, there are also a number of current legal issues - e.g. Danish demands for equal mobility in both directions on exchange programmes, restrictions on how international scholarships can be spent, and collaboration with funding institutions - that make it more difficult for Danish universities to collaborate on joint programmes with HEls abroad (DAMVAD, 2014; 2013).

The Nordic Council of Ministers provides one-off grants for the establishment of Nordic Master programmes. This has meant that the academic environments involved were forced to find a sustainable funding model in order to keep the programme running for a prolonged period. According to one associate professor at the University of Copenhagen, this can reduce the motivation to invest energy into collaboration, because staff may have no idea whether a programme will continue in the long term. In the latest round of applications to the Nordic Master Programme, the Council of

${ }_{12}$ Nordic Master Programme - Legal and administrative obstacles, Nordic Council of Ministers (2015), TemaNord2015: 528. 
Ministers introduced a funding model that stretches over longer periods (up to five years) and reduces financial uncertainty. Stable funding is a crucial factor in ensuring that the parties involved in collaborations are motivated to put in the effort needed to keep them going.

Several interviews cited lack of funding and the range of funding models in the different countries as an obstacle to collaboration. Competition for students is intense, and in several cases it was not considered to be in the institution's interests to send students to other HEls, as there was no financial benefit. For a collaboration to be considered worthwhile, there must be an economic benefit for all of the parties involved (Head of Studies, Ancient Cultures and Classical Languages, University of Oslo; Dean of the Faculty of Arts, University of Helsinki). The Head of the Department of Comparative Literature at the Norwegian University of Science and Technology pointed out that all Norwegian universities are required to make savings, so collaboration is not always their top priority. The associate deans of the University of Helsinki and the University of Tromsø emphasise that it is difficult to find funding for Nordic co-operation. Previously, HEls could apply to the Nordic Master Programme for large one-off grants to establish collaboration and lay the foundations for the actual programme. This is no longer the case. For the latest round of applications to the Nordic Master Programme, the Council of Ministers introduced a funding model that invites applications for funding for a period of up to five years. This is designed to guarantee greater certainty about the funding of joint activities. Stable funding is a crucial factor in ensuring that the parties involved in collaborations are motivated to put in the effort needed to keep them going. The Erasmus + programme provides small grants for threeyear periods. The Head of Studies and Head of Department at Aarhus University and a lecturer at the University of Copenhagen pointed out that work on CSC at national level has to cope with the lack of national funding schemes equivalent to the Nordic and European ones. Until now, this has made it difficult to establish joint degrees at national level. The associate dean from the University of Aarhus emphasised that it is important to face up to the challenges confronting small subjects by exploring the potential for joint degrees at national level. The dean from Stockholm University also pointed out that budget allocations are also a problem in CSC projects..

\subsubsection{Concentration}

The interviews revealed that concentrating subjects is often difficult because it faces greater opposition that collaboration and specialisation. In Finland, there have been many examples of concentration. In recent years, there has been a great deal of focus on concentration via the profiling of the universities, each of which has its own core competencies. Norway, too, had a process of concentration at national level. The Associate Dean of Education at the University of Oslo emphasised that successful concentration depends on highly motivated individuals in the academic environment concerned. The academic environments must prioritise at national level. The challenge consists of the fact that concentration entails closing departments, which can lead to disagreements regarding the prioritisation of subjects, as some are more popular to run 
than others. Special interests within the departments can also make concentration difficult.

The Associate Dean at Aarhus University pointed out that concentration is difficult because many students who move to Copenhagen choose to remain there after graduation. Concentrating subjects in particular locations makes it difficult to meet the needs of employers across the country. The associate dean from the University of Oslo and the dean from the Faculty of Humanities at Stockholm University identified a potential unintended consequence of concentration - namely that if a study programme is closed, students may choose a different programme rather than move with the subject. The Head of Classical Languages at the University of Oslo also pointed this out, and noted that Norwegian students usually choose the university closest to where they live, and have little desire to travel to take a particular subject. It is therefore questionable whether concentration will achieve the desired effect. On the other hand, the Head of Studies at Aarhus University argued that many of the students who choose to study specialised, vulnerable subjects are particularly dedicated and would accept the need to relocate. The content of the study programme can, therefore, have an impact on students' willingness to move.

The Dean of the School of Humanities at the University of Iceland emphasised that, due to the institution's size, there are many subjects that the university cannot teach, so students have to take them in other Nordic countries. Rather than closing all vulnerable programmes due to falling student numbers, the associate dean suggested that it may be preferable to organise the concentration of vulnerable subjects at ministerial level, in order to improve their chances of survival. The University of Copenhagen is also in the process of merging a number of vulnerable subjects to make them financially sustainable. The associate dean noted that a Nordic strategy may be needed for concentration, rather than a wide geographical spread, in order to ensure that the universities involved have sufficient funding. The dean from Stockholm University pointed out that as long as the Nordic governments are not involved, it will be very difficult for concentration to succeed. This is partly because it is unclear who has responsibility for administration, and partly because of the way in which budgets are allocated.

While there are a number of strengths and advantages to CSC work on vulnerable subjects, there are still many hurdles to overcome. The following section highlights experiences from previous Nordic CSC projects.

\subsection{Experiences of Nordic CSC projects}

The experiences compiled by the study indicate that collaboration is the easiest aspect of CSC work to establish, especially on a more informal basis. Specialisation and concentration are more difficult due to the institutions' self-interest. HEls are much more sceptical of specialisation and - in particular - of concentration, because both of these aspects of work on CSC might entail them having to give something up. However, the interviews also highlighted the fact that collaboration is not always problem-free, 
and that there are a range of challenges associated with this form of CSC work. Collaboration usually succeeds when it is based on good regulatory and administrative frameworks - see the East European Studies case study in Section 5.2. Similarly, there is a greater chance of success when collaboration is established by enthusiastic staff. One challenge highlighted by the HEls is the start-up costs for collaborations. However, investment in Nordic CSC projects can help save vulnerable subjects and guarantee their long-term financial sustainability. While the interviewees could see potential in Nordic CSC initiatives as a means of ensuring the survival of vulnerable subjects, there was a noticeable reluctance among the HEls to enter into collaboration projects. However, if they fail to invest in long-term, sustainable solutions, they run the risk of closure(s) as a consequence.

Since 2010, the Norwegian Ministry of Education and Research has allocated funds for work on both national and Nordic CSC projects. Grants have been given to a number of national collaboration projects involving vulnerable humanities subjects, and to help set up Nordic collaboration initiatives, especially in language subjects. Much like this study, the experiences gained from these CSC projects show that collaboration between Nordic HEls is relatively easy to set up, and usually more successful than setting up specialisation and concentration projects. Nordic collaborations have a good chance of success because there is less internal competition, e.g. on the recruitment of students, than there is between HEls in the same country (National Faculty Meeting for Humanities, 2014). Concentration projects, at both national and Nordic level, require a different form of organisation and different mechanisms. The reason for this is that successful academic concentration is generally a long-term process that requires major changes. It is made difficult by factors such as the HEls' internal competition and their desire for autonomy. In a similar vein, different methods of organising studies can act as a barrier to CSC initiatives.

The Norwegian National Faculty Meeting for the Humanities (2014) identified a number of organisational factors that have a bearing on the extent to which CSC work is successful. Firstly, experience from previous CSC projects shows that bilateral collaboration projects have a good chance of success, because it is easier to guarantee that the initiative will serve the interests of both parties. Secondly, there are advantages to be gained from using collaboration on teaching as a basis for research collaboration, because prior experience of working together makes it easier to establish new forms of collaboration. Thirdly, continuity over time also plays a role, as management changes can complicate CSC processes. Fourthly, working together on the administrative aspects and support within the HEls involved are also prerequisites for the success of work on CSC projects. 


\section{Case studies}

For this study, we conducted a series of interviews with associate deans and deans of humanities faculties throughout the Nordic Region. The interviews provided information about existing national and Nordic CSC initiatives designed to protect vulnerable subjects, and highlighted their strengths and weaknesses. Based on these interviews and the initial desk research, we identified a number of categories under which most types of collaboration can be placed, and selected four cases, which are presented in this chapter. The cases were chosen because they illustrate the extent to which the different forms of CSC work are useful in practice.

\subsection{CSC models}

The interviews with associate deans and deans identified four main types of CSC initiatives. These are:

- Working together on courses (collaboration).

- Working together on language subjects with universities in the country where the language is spoken (collaboration).

- Joint master's programmes (specialisation).

- Concentration.

The first type of collaboration is the easiest to set up, as it does not require any of the parties to give anything up in order to be part of the project. Working together on courses means that HEls retain their academic and research environments. This type of initiative focuses on academic exchanges, which makes it easier to secure support, both nationally and across the Nordic countries. It also provides obvious academic and study benefits, in the form of a bigger and wider range of courses and, potentially, a boost to research. One example of this is the Nordic Master Programme "Viking and Medieval Norse Studies" - see the case description in Section 5.2. However, according to the Head of Study and Head of the Department of Communication and Culture at the University of Aarhus, there is very little to be gained from working together on courses in purely financial terms because it requires so much time and planning.

Languages comprise the majority of the subjects covered by our definition of vulnerability, and therefore working with other HEls in the country in which the language is spoken is an obvious choice. The interviewees emphasised that this second type of CSC initiative usually consists of sending students to study abroad to improve their language skills and their understanding of the culture and history of the country in question. Where 
the language being studied is spoken outside of the Region, a Nordic approach is a less obvious solution, unless it is possible to establish Nordic student exchange programmes, as in the case of China Studies (see the case study in Section 5.2).

The third type of collaboration, on a joint master's programme, requires that students spend whole semesters at other universities. One example of this is the Erasmus Mundus programmes, which provide students with mobility funding to study abroad for a semester. The mobility requirements inherent in this type of CSC initiative mean that students must be willing to relocate. On the other hand, employees often consider it an advantage that graduates have gained experience of different and international environments during the course of their studies.

The fourth type of CSC project - concentration - provides HEls with an opportunity to raise their profile based on their strengths. Concentration can help raise student numbers and enhance the academic environment and quality in the institutions where the subject is subsequently taught. Concentration can also help make subjects financially sustainable.

\subsection{Case studies}

Along with the Head of Studies and the Head of the Department of Communication and Culture at the University of Aarhus, we have selected a series of best-practice models for work on CSC. Based on our desk research and interviews with deans and associate deans at ten Nordic universities, it would appear that there are very few examples of CSC projects involving subjects that fall within our definition of vulnerability. As a result, the best-practice models refer to both vulnerable and non-vulnerable subjects. The following section presents four successful Nordic CSC models

East European Studies is a good example of working together on courses, and takes the form of a collaboration between the University of Copenhagen and Lund University. It is a relatively loose arrangement at bachelor level, but the ambition is to introduce a more established form of collaboration at master's level. This would be an appropriate approach, because study structures at master's level are usually more flexible than at bachelor level, which means that they lend themselves more naturally to Nordic cooperation. Student numbers at master's level are generally lower than on bachelor programmes, which makes the subject more vulnerable at master's level.

Subject area: East European Studies.

Countries

Denmark and Sweden.

HEls

Department of Cross-Cultural and Regional Studies (ToRS), University of Copenhagen (KU) and Lund University (LU). 
Target group

BA + MA students.

\section{Type of collaboration}

Exchange programme for lecturers, with plans for joint courses and joint master's programmes next year. Example of CSC initiative.

\section{Start date}

Spring 2016.

\section{Organisation}

Exchange programme for lecturers: LU provides lecturers in Central and Eastern European history to $\mathrm{KU}$, which provides lecturers in Balkan Studies to Lund.

Joint course: $\mathrm{KU}$ and LU are planning a joint course focusing on thematic problems. They expect to exchange both lecturers and students as part of the joint course.

Joint master's programme: At master's level, KU and LU are looking at ways to set up an actual joint study programme: an English-language "MA in East European Studies with a language component and study programmes/specialisation in advanced Russian".

\section{Strengths}

Exchange programme for lecturers: the initiative emerged from academics working together at grassroots level. Good contacts between CPHU and LU paved the way for informal collaboration agreements to provide each other with teaching resources. The exchange programme for lecturers has been possible due to an existing formal collaboration between $\mathrm{KU}$ and $\mathrm{LU}$, which enables students to follow classes at either. The relatively short distance between the two has also been a strength.

Joint course: The motivation to consider collaboration and specialisation was very much about taking advantage of core academic competencies across borders. The Department of Cross-Cultural and Regional Studies (ToRS) at CPHU conducts research into history, cultural studies, social studies and literature, Holocaust studies and language policies, with a focus on Russia, the Balkans and Poland. KU runs classes in Polish, Russian and Bosnian-Serbo-Croat. LU conducts research into politics and foreign policy, communism, ethnography and history, with a focus on Central and Eastern Europe (Poland, Ukraine and the Czech Republic). The collaboration was designed to provide breadth to the range of courses available within the subject and to allow students to be taught by leading experts in their field.

Joint master's programme: A joint master's programme would make East European Studies stronger as a subject. The collaboration is designed to maintain the areas already covered by the subject and to facilitate the introduction of new areas.

\section{Challenges}

Exchange programme for lecturers: Exchange programmes place mobility demands on lecturers, who have to be more flexible.

Joint course: The challenge is that it can be expensive for students to takes subjects on the other side of the Øresund. Student flexibility can also be reduced due to the fact that joint programmes require concentrated teaching days in Sweden and Denmark, rather than a standard timetable. The frameworks for how courses are run, as well as the differences in structures between the countries, also pose challenges. Sweden traditionally runs smaller, shorter courses with a very specific focus, while ToRs runs large programmes (up to 15 ECTS credits).

Joint master's programme: Administration is a major challenge and requires considerable resources. It is also difficult to put together the budget for administration. Formal collaboration on joint programmes requires restructuring, which is a challenge because it is difficult for the individual study programmes to 
make changes to their curricula. Establishing joint programmes is also time-consuming: it takes longer to obtain approval for new programmes at management and accreditation level.

Source

Interview with the Deputy Head of Studies at ToRS and an assistant professor of Balkan Studies at KU, and interview with the Director of Studies for Central and Eastern European Studies at LU.

Viking and Medieval Norse Studies depends, according to the Head of Studies and Head of Department at Aarhus University (AU), on enthusiastic academics and good international partners. It is a bottom-up initiative driven by the staff's desire to develop their own academic environment. Collaboration has made it possible to develop the subject and increase intake thanks to international students. Prior to the establishment of Viking and Medieval Norse Studies, there was no master's programme in this field. Viking and Medieval Norse Studies is an example of a joint master's programme.

\section{Subject area: Viking and Medieval Norse Studies}

Countries

Denmark, Iceland and Norway.

Institutions

University of Iceland (HI), Aarhus University (AU), University of Copenhagen (KU) and the University of Oslo (UiO).

Target group

Master's students.

Type of collaboration

Joint Nordic Master Programme; example of collaboration and specialisation.

Start date

2010.

Organisation

Viking and Medieval Norse Studies is a two-year international master's programme taught in English. The first two semesters take place at the University of Iceland (HI) in Reykjavík. For the third semester, students can study at Aarhus University (AU), the University of Copenhagen (CPHU) or the University of Oslo (UiO). In the fourth semester, students write their theses at $\mathrm{HI}$ or UiO. Depending on where students opt to spend the third semester, they are awarded either a joint degree from $\mathrm{HI}$ and $\mathrm{UiO}$, or a degree from $\mathrm{HI}$ with a supplementary diploma from $\mathrm{AU}$ or $\mathrm{UiO}$.

\section{Strengths}

Viking and Medieval Norse Studies is rooted in Scandinavian heritage, which provides a good basis for collaboration at Scandinavian level. Two of the Departments involved, the Árni Magnússon Institute for Icelandic Studies in Iceland and the Arnamagnæan Institute at KU, also share the world's largest collection of medieval Icelandic manuscripts. 
This programme draws on expertise from all four of the universities in Norse literature, linguistics, history, textual criticism, palaeography, runology, folklore, religion, art and archaeology. Collaboration means that the programme is able to run more courses for students and to draw on guest lecturers from the Nordic countries.

It also makes it possible to preserve a narrow subject area, as it depends upon the four universities working together and complementing each other. The collaboration agreement offers students an international-class research programme and the best lecturers available.

The parties involved consider the collaboration to be a great success. None of the universities would have been able to offer an international study programme of comparable quality on its own.

Challenges

One of the challenges with which the collaboration project has to contend is the fact that the different countries have different ministerial orders for their study programmes. Due to the Danish accreditation requirements, $\mathrm{KU}$ and $\mathrm{AU}$ are only associate partners, while $\mathrm{UiO}$ and $\mathrm{HI}$ are full partners. This is because one of the Danish accreditation criteria is that there must be some prospect of students being able to find work in Denmark. It is difficult to meet this criterion in such a narrow subject area. On the other hand, this is not necessarily an issue for international students who intend to seek employment in other countries. The small student numbers also make it difficult for the programme to achieve accreditation. The requirements were developed in a Danish context but are not particularly appropriate when setting up an international programme. According to $\mathrm{HI}$, this creates a structural imbalance in the programme, as students can take two semesters in Norway, but only one in Denmark. $\mathrm{AU}$ sees this as a challenge, but not as something that has an impact on where students spend the third semester.

In addition, $\mathrm{UiO}$ and $\mathrm{HI}$ do not charge tuition fees for either Nordic or international students. In Denmark, on the other hand, non-EU students must pay tuition fees. This makes it much more attractive for non-EU students to choose HEls without tuition fees, which can upset the balance between the partners.

Establishing joint programmes also requires significant resources and a strong administrative setup. The interviewees expressed surprise at the extent of the administrative work required. An associate professor at $\mathrm{AU}$ also noted that the low student numbers present a local challenge for $\mathrm{AU}$ and could become crucial for whether the University will continue to be part of the collaboration.

Source

http://english.hi.is/viking_and_norse_medieval_studies/viking_and_medieval_norse_studies and interview with an associate professor at $\mathrm{AU}$, a professor from $\mathrm{UiO}$ and a head of studies at $\mathrm{HI}$.

China Studies: In contrast to Viking and Medieval Norse Studies and East European Studies, China Studies was developed from the top down. However, it is also driven by the academics involved, who the interviewees describe as enthusiasts for their subject. The collaboration project was a major investment on the part of the HEls, in terms both of finances and organisation. China Studies is an example of Nordic collaboration and of collaboration with the country in which the language is spoken. The collaboration with China is designed to ensure that the students attain appropriate academic standards. 


\section{Subject area: China Studies}

Countries

Denmark, Sweden and Norway.

Institutions

Stockholm University (SU), University of Oslo (UiO), Aarhus University (AU), University of Copenhagen (CPHU).

Target group

Lecturers and students.

Type of collaboration

Nordic Consortium for China Studies (NCCS), Erasmust, example of both collaboration and specialisation.

Start date

2012.

Organisation

NCCS coordinates and supports the transnational two-year Nordic/Chinese Master's in China Studies. The programme consists of a collaboration between NCCS and Zhejiang University in Hangzhou. It culminates in a double degree from one of the Nordic partner universities and Zhejiang University. The first and fourth semesters are spent at one of the Nordic universities, the second and third at Zhejiang University.

NCCS also facilitates the Nordic Network of Teaching Chinese as a Foreign Language (NordNet of TCFL), an academic organisation for lecturers of Chinese in HEls in the Nordic Region. NordNet of TCFL is a platform that enables exchange programmes for lecturers between the Nordic universities, and also conducts Nordic research in the area.

The project budget is highly transparent. SU has the main responsibility for the budget. However, a large portion of the budget has been allocated to AU deal with the administration, because it has the most experience and expertise in this type of collaboration.

\section{Strengths}

China Studies is a concrete example of collaboration with a country where the language is spoken. It provides students with the opportunity to improve their language skills and gain insights into the cultural and historical context of the country.

The Chinese partners are highly committed and have ambitions of developing the study programmes.

The collaboration also assures that the quality of the subject is improved at the Nordic HEls by drawing on research and lecturers from different institutions. NCCS aims to pool expertise in its field, ease the administrative burden and improve strategic, organisational and communication platforms for China Studies at all of the universities taking part in the collaboration. The collaboration also provides China Studies with a stronger and more visible profile at international level.

The programme is partly funded by Erasmus+ and has the advantage that it is based on clear agreements drawn up for Erasmus Mundus, which provide clear guidance on how to establish collaborations. The advantage of using a predefined setup template for collaboration is that it helps reduce the administrative burden. 


\section{Challenges}

Establishing joint programmes requires significant resources and a strong administrative setup. A professor of Chinese Studies at SU reported that the administration involved is more time-consuming and more complicated than expected. The educational cultures and traditions in the Nordic countries and at the Chinese university are also very different. This presents difficulties because it leads to different expectations about the form and content of the teaching, which may detract from the benefit students derive from their stay in China. The Head of Studies at UiO noted that the quality of teaching at the University of Zheijang is too low. The flow of information to students is also less than optimal, and the exams are poorly organised.

The collaboration represents a financial burden for the Nordic universities, as a large proportion of the funding goes to the Chinese university. The Head of Studies at UiO pointed out that the four universities share costs equally between them. However, when the students go to China for a year, they lose revenue based on the ECTS credits that the students would otherwise have earned at their Nordic universities. The collaboration agreement obliges the Nordic universities to run certain courses, which also represents a cost. The oral exams also have to be held in the Nordic Region, which requires the presence of four professors, and constitutes another major expense. Although funding has been allocated to the Nordic universities for the further development of the programme, the collaboration is still not financially advantageous, as they spend more than they get back.

UiO and CPHU have doubts about whether the collaboration will be extended due to the low and still declining - number of applicants and the very tight budget. An associate professor at KU pointed out that if applicant numbers continue to fall, no funding mechanism will be in place to keep the programme running in the longer term. However, $\mathrm{SU}$ is not under the same degree of financial pressure, as Swedish academia is not facing the same level of cuts as Norway and Denmark.

\section{Source}

http://www.su.se/asia/english/nordic-consortium-for-china-studies and interviews with an associate professor at $\mathrm{CPHU}$, a head of studies at $\mathrm{UiO}$ and a professor at $\mathrm{SU}$.

\section{Subject area: German and Russian}

\section{Countries}

Finland.

Institutions

University of Turku (UT) and the University of Eastern Finland (UEF).

Target group

Students.

Type of collaboration

Example of work on concentration.

Start date

2017.

\section{Organisation}

In 2017, the University of Eastern Finland (UEF) will stop teaching German and relocate the subject to the University of Turku (UT). Conversely, UT will drop Russian, which will be relocated to UEF. The 
idea behind this concentration is to raise the profile of the two universities and exploit their respective strengths. UT has been teaching German since 1925 and benefits from that the fact that several large German companies operate in the city. It is also geographically closer to Germany than UEF. The latter, on the other hand, is adjacent to Russia, and the Russian language plays an important role in eastern Finland. UEF's location in Joensuu makes it a good place to study Russian, because the language is spoken in the city and the border is less than an hour away.

The background for this particular concentration was a wide-ranging reform of the Finnish universities, which has reduced the number of universities via a process of mergers from 20 to 15 since 2009. Another result of the reform is that other universities are not allowed to offer the same subjects in an attempt to fill vacant student places.

Strengths

Until next year, German will be taught at eight universities in Finland, all of which have spare capacity on their study programmes. Concentration is designed to increase student numbers and allow the respective institutions to specialise and make the most of their strengths.

\section{Challenges}

Turku has made a commitment that students who enrol on its Russian course this year will be able to take a full master's programme at EQF level 7. This throws up another challenge, however, in that the University only has in place lecturers for the next three years, not for the remaining two.

\section{Source}

Interview with a head of studies and a dean from UT and interview with a dean from UEF. 


\section{Nordic potential}

This section aims to put into perspective the potential for Nordic co-operation and how cross-border work on CSC can help to generate Nordic added value. Based on the cases presented in Chapter 6, we asked a number of heads of departments, heads of study and lecturers to assess how the various collaboration models work and whether they could be applied to their own subjects.

\subsection{Assessments of the different CSC models}

We interviewed a number of heads of departments, heads of study and lecturers on vulnerable subjects and asked them to assess the various CSC models presented in the case studies in Chapter 6 and whether they could be applied to their own subjects. The section below is based on their responses.

\subsection{Working together on courses}

In general, geographical distance is considered a challenge, so the short distance between Copenhagen and Lund was consistently referred to as one of the strengths of the collaboration on Eastern European Studies. The Head of Studies in Ancient Cultures and Classical Languages at $\mathrm{UiO}$ sees working together on courses as an obvious CSC model for departments that are not very far from each other. An associate professor of Italian at $\mathrm{KU}$ also referred to it as a strength that HEls that are close to each other can draw on each other's expertise. In the case of Eastern European Studies, students from both $\mathrm{KU}$ and LU benefit from the partner universities' different specialisations. An associate professor at KU believes that this case is the most relevant to his subject, and sees it as a potential CSC model for Italian. The coordinator for French at AU also sees this model as a possibility for French. She believes that the distance between Aarhus and Lund is short enough for students to be able to travel between the two.

Several of the interviewees mentioned that the short distance between Copenhagen and Lund was a particular strength of this collaboration. The model would not necessarily work well for HEls further apart. Mobility requires resources, and both lecturers and students must be willing to travel. In summary, collaboration on courses and exchange programmes for lecturers and students between HEls that are geographically close to each other is deemed to have a high probability of success. 


\subsubsection{Joint master's programme}

Several of the interviewees mentioned joint master's programmes as a potential model for their own subjects (e.g. the Head of the Department of Musicology, Uppsala University; the Head of Department of Comparative Literature, Norwegian University of Science and Technology). The Head of the Department of Musicology at Uppsala University considered this to be the most appropriate model. The Department has already discussed the possibility of setting up a joint master's with a partner, and sees the way in which the Viking and Norse Studies programme is organised as a particularly positive example. The Head of Comparative Literature at the Norwegian University of Science and Technology also said that she sees opportunities for collaboration at master's level, which would enable students to travel around the Region to study Nordic writers. It would also help to strengthen the internationalisation of the programme. The internationalisation perspective was also important for the Dean of the Faculty of Arts at the University of Helsinki, who sees potential in transferring this model to subjects like general cultural studies and archaeology. He pointed out that the strength of model is that the subjects are able to raise their international profile.

However, the Head of Studies in Ancient Cultures and Classical Studies at UiO pointed out that this model would potentially present a challenge to her subject in that the universities would be competing with each other to attract students in the third semester. She thinks that it is important that the model takes this competitive aspect into account. This particular challenge was not stressed in interviews with the universities involved in Viking and Norse Studies. All of the partners involved agree that the joint master's programme has worked as well as possible. The Professor of Viking and Norse Studies at UiO emphasised, however, that it would be an advantage for the universities to work on their individual profiles so that they differentiate themselves from each other when students come to choose their elective subject in the third semester.

\subsubsection{Collaboration on languages in the countries where they are spoken}

The interviewees consider the CSC model on which the China Studies case is based to be the most relevant for language programmes. Several of them described it as a good model, but only for languages (Head of Department of Comparative Literature, Norwegian University of Science and Technology; Associate Professor of Musicology, Norwegian Academy of Music). Italian at KU is involved in a similar project. The Associate Professor mentioned that a deal has been struck with a university in Italy to which students are sent as per an Erasmus exchange programme. He stressed that students are usually most interested in exchange schemes with the country where the language that they are studying is spoken. 


\subsection{Concentration}

Concentrating vulnerable study subjects has financial benefits. However, several of the interviewees expressed concern that it can also mean the end of subjects in certain institutions, which can have implications for staff and students (Head of Studies in Antique Culture and Classical Languages, $\mathrm{UiO}$ ). Other benefits of the model are that it raises the profile of the HEls involved and can create a bigger learning environment that attracts students who would otherwise have chosen other programmes (Head of Department of Musicology, Uppsala University).

\subsection{Opportunities for Nordic CSC projects}

Some vulnerable subjects face being dropped if they fail to strengthen and to enhance the quality of their study programmes. The case studies present examples of successful CSC models that can help save vulnerable subjects. HEls face increasing demands to cut spending, so it is important to look at how CSC projects can help them survive.

Most of the interviewees acknowledged the need for Nordic co-operation. A large proportion of them see it as a strength to work together at Nordic rather than national level. However, the language subjects also underline the advantages of collaboration agreements with the countries where the languages are spoken. Some of the informants from study programmes that have problems achieving critical mass expressed a great need for collaboration, because running study programmes with low student numbers is an expensive business. In general, the interviews show that the greatest need for Nordic co-operation is at master's level, because master's programmes find it more difficult to achieve critical mass, whereas bachelor programmes do not encounter the same difficulties with recruitment.

The Head of the Department of Comparative Literature at the Norwegian University of Science and Technology sees a need to promote more cross-border learning as a means of continuing to develop comparative literature as a subject, but also pointed out that one of the challenges facing more formal types of collaboration in Norway is that students are reluctant to travel within Norway. According to the Head of Department, this is partly due to many of them having part-time jobs to help pay for their studies, and partly because students enjoy high levels of funding in Norway and are able to maintain a good standard of living, which they do not want to give up. On the other hand, the 2014/2015 "Open Doors" report by the Institute of International Education shows that Norwegian students are much more willing to travel abroad and participate in more exchange programmes than, for example, Danish, Finnish or Icelandic students. The Head of Studies in Ancient Cultures and Classical Languages at UiO mentioned that a previous national CSC project involving the subjects Classical Archaeology and History found the mobility requirement particularly challenging. Coordinating the teaching required a great deal of effort, because students found it difficult to get to their classes on time when they had to travel around the country. They also faced having classes in more than one place at the same time if teaching in different 
subjects overlapped. There was, therefore, a risk of students missing classes as a direct result of the collaboration. Another challenge was that the academic focus was too broad, as it had to accommodate many different subjects. In the future, therefore, any similar CSC project would only be in the classical languages.

One way to overcome the mobility challenges posed by long distances is to make use of online courses. Digital solutions overcome physical limitations and provide more options for working together. In the interviews, several of the heads of studies spoke of the need to develop opportunities for web-based Nordic collaboration. The Head of Studies in Linguistics at SU mentioned that web-based solutions are important for retaining students who are not willing to study abroad. Online courses can also help attract new students and reduce the costs of establishing new Nordic CSC projects. On the other hand, online courses have an impact on the local study environments at HEIs. Web-based courses increase the distance between lecturers and students. Students do not have the same level of direct interaction and personal dialogue with other students and lecturers that they do in physical learning environments. With this in mind, it may be a good idea to combine online courses with classes at a particular location, so that students still enjoy the benefits of a strong study environment.

If these mobility challenges can be addressed, the Head of the Department of Comparative Literature sees great potential in collaboration across the Nordic Region. Copenhagen and Stockholm, for example, have bigger study environments for comparative literature than the Norwegian University of Science and Technology. Collaboration with them would provide students with more opportunities and make the programme more international. The Head of the Department of Comparative Literature at the Norwegian University of Science and Technology noted a tendency for the English language to become dominant in comparative literature, and sees Nordic CSC projects as a way of preserving the Scandinavian languages. CSC projects can, therefore, be seen as important tools for strengthening the Scandinavian languages.

French at AU has been working with Aarhus School of Business, and language programmes at the latter will be moved to the Faculty of Arts at the University in 2017. This will raise academic standards and improve the content of the study programmes. Aarhus University wants to retain and improve the skills of the students it already has, and sees a range of financial benefits in the collaboration, as it will provide a boost to student numbers. In purely academic terms, the collaboration is expected to be rewarding for both groups of students, because it will allow them to gain an understanding of how their language skills can be used in a broader, application-oriented employment perspective (coordinator, French Studies, AU). This model can also be scaled up-in a Nordic context, multiple HEls can work together throughout the Region.

The Head of Studies in Philosophy at SDU mentioned that much of the teaching is provided by other subjects, which gives opportunities for greater diversity and for a broader academic profile, because students can have elective studies taken at other Danish universities accepted as part of their programme. In other words, students are able to choose from a huge range of elective subjects at other HEls. Making it possible for students to take subjects in other Nordic countries would, therefore, expand the course catalogue. The head of studies thinks that the strength of CSC projects in relation to 
philosophy lies in the fact that the subject is highly diverse, with many different approaches and schools of thought. A single department can find it difficult to cover all of this, which makes collaboration an attractive alternative. The Nordic philosophy departments run an annual one-week Nordic Summer University. This has had a significant impact on the sense of affinity across national borders (Head of Studies in Philosophy, SDU). The Head of Studies in Linguistics at SU also sees advantages in projects that offer students a wider selection of subjects from which to choose. However, as far as linguistics is concerned, he does not think that there is any need for specialisation, as the necessary skills already exist within the academic environment.

It is clear from the interviews that many vulnerable subjects see the potential advantages of Nordic CSC initiatives. Nordic collaboration also offers a way to exploit the shared cultural and linguistic heritage to generate economies of scale, which will benefit students, academic environments and society throughout the Region. However, the study only identified a limited number of vulnerable subjects that have already established Nordic collaboration, even though it is seen as an important tool that HEls can use to ensure strong and viable academic environments. As such, there is still unexploited potential in vulnerable subjects to work together. If these subjects are to survive, they must pay more attention to opportunities to strengthen themselves via CSC initiatives. Uniform frameworks for CSC projects at ministerial and Nordic level are also needed in order to facilitate the establishment of agreements and provide financial support to vulnerable subjects during the establishment phase. The study also shows that there is huge untapped potential for work on CSC in vulnerable study programmes. If these subjects are to survive, they must pay more attention to opportunities to strengthen themselves via CSC initiatives. 



\section{Methodology}

The study was based on a review of previous studies in the area, supplemented by qualitative and quantitative data. It took into account the national context within which each Nordic country operates, and incorporates knowledge of national frameworks and political priorities.

Figure 5 uses "the Knowledge Funnel" to illustrate our analytical approach. We start at the top and move down through the demarcation of vulnerable subject areas, to collating knowledge about them, to the preparation of proposals for intervention and CSC initiatives.

Figure 5: The Knowledge Funnel - study design

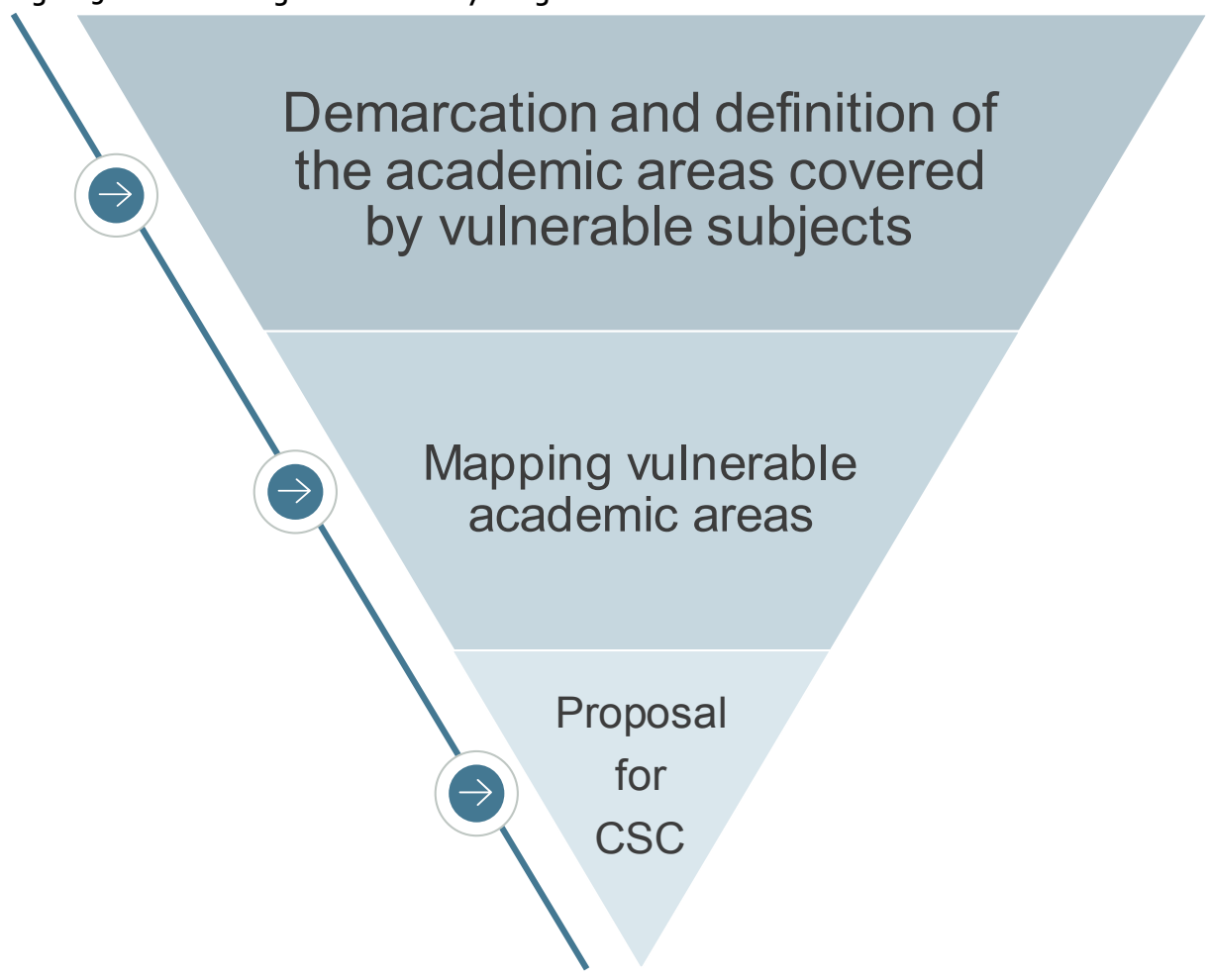

Source: DAMVAD Analytics 2016. 


\subsection{Qualitative methodology}

The qualitative component consisted of desk research, qualitative interviews and case studies.

Desk research consisted of a review of Nordic ministerial websites, publications and legislation. We also reviewed national and international studies of various demarcations and definitions of work on CSC.

We conducted 39 interviews with one or more representatives of the Nordic ministries, deans, associate deans, lecturers, heads of study and heads of department in order to illustrate different parts of the study. The interviewees are listed in Appendix 1.

The interviews with ministries provided information about whether the various countries have a working definition of vulnerable subjects. The purpose of the interviews was to qualify the knowledge gathered in the desk research. We also asked supplementary questions about future national policy intentions for subject areas. The combination of qualitative interviews and desk research provided a basis for a qualitative definition. However, it is important to be aware of the significant differences in the extent to which the various countries focus on vulnerable subjects and on CSC work. In a similar vein, there is considerable variation in the level of knowledge about these issues in the individual countries, which explains the differences in their qualitative definitions. For example, in Sweden there has only been a limited focus on this issue, while Norway has worked on CSC projects for many years.

Interviews with associate deans and deans of humanities faculties across the Region have provided knowledge of existing national and Nordic CSC initiatives concerning vulnerable subjects and highlighted their strengths and weaknesses. The interviews also helped validate the key data collected for the HEls. The interviews and desk research led to the selection of four case studies that formed the basis for an indepth study of the extent to which the different forms of CSC work are useful in practice. These cases also informed the interviews with heads of departments, heads of study and lecturers. We used the case studies and interviews to look at the main challenges facing the various types of collaboration. They also provided insight into the potential for collaboration and for generating greater Nordic added value in future.

Our interviews were based on a semi-structured guide - a majority of the questions were defined in advance, but there were also opportunities to pursue relevant new points that arose during them. The guide was sent to interviewees in advance, because the interviews required a great deal of reflection and a certain amount of preparation, in terms of gathering information and data. This gave the interviewees an opportunity to reflect on and prepare answers for questions before the interview. 


\subsection{Quantitative methodology}

The quantitative parts consisted of acquiring data from a wide range of public databases in the Nordic countries.

First, a series of relevant parameters were identified:

- Intake.

- Dropout rates.

- Completion time.

- Completion rate.

- Student numbers.

- Academic staff.

- Budget.

Firstly, searches were conducted of all the national Nordic statistics databases for data on the above parameters. This was supplemented with data from various relevant government agencies in each country's education sector. Data was acquired from the Coordinated Admission System (KOT) in Denmark, the Council for Higher Education (UHR) and the Higher Education Authority (UKA) in Sweden, the Norwegian Centre for Research Data's (NSD) "Database for Statistics on Higher Education" (DBH), Statistics Finland, Statistics Greenland and Statistics Iceland. See the data appendix for a detailed list of sources.

The various sources were combined to create a single database incorporating all of the parameters listed above. The objective was to be able to make comparisons across academic programmes. This is why the individual study programme was used as the controlling variable with which all other parameters were correlated. When correlating data, we took into account the differences in the definitions and organisational levels used by the different data sources.

Correlating multiple national data sources in this way enabled the creation of a unique Nordic database of vulnerable subjects. This database provided the foundation for the qualitative definition and for the mapping exercise in Chapter 3. 



\section{Bibliography}

Aarrevaara, Timo, Ian R. Dobson and Camilla Elander (2009): Brave New World: Higher Education Reform in Finland. Higher Education Management and Policy 21/2, OECD 2009.

ACE Denmark \& DAMVAD (2011): Forskningsbasering i universitetsuddannelser - En tværgående opsamling af uddannelsesakkrediteringer fra 2010 og 2011.

Ad hoc gruppen för SAK (2013): Rapport ad hoc grupp för Samarbete, arbetsdelning och koncentration (SAK). Nordiska ministerrådet.

Centre for International Mobility (2016): Universities in Finland. Posted on 10 October 2016: http://www.studyinfinland.fi/where_to_study/universities

DAMVAD (2015): Dimensjonering av høyere utdanning. Samfunnsviterne.

DAMVAD (2014): Fælles uddannelsesforløb: omfang og muligheder. Uddannelses- og Forskningsministeriet.

DAMVAD (2013): Öresundsregionalt universitetssamarbejde på uddannelsesområdet. Öresundskomiteen.

Danmarks Akkrediteringsinstitution \& DAMVAD (2014): Små humanistiske uddannelser Opsamlende analyse fra Danmarks Akkrediteringsinstitution April 2014.

European Commission (2016): Descriptors defining levels in the European Qualifications Framework (EQF). Posted on 20 September 2016:

https://ec.europa.eu/ploteus/en/content/descriptors-page

Finansministeriet (2016): Forslag til finanslov for finansåret 2017.

Gaia Consulting (2015): Mapping of Nordic university co-operation onresearch 2015. NordForsk.

Göteborgs universitet (2013): Små ämnen: samarbete, arbetsfördelning och koncentration vad kan vi göra i Norden? Hentet den 20. september 2016 fra http://www.helsinki.fi/halvi/srno/svenska/internationellt_samarbete/NUS_Rektorsseminarium 2013/Fredman_010313.pdf

Joanneum Research \& DAMVAD Analytics (2015): The Leverage Potential of the European Research Area for Austria's Ambition to become one of the Innovation Leaders in Europe: A comparative study of Austria, Sweden and Denmark. The Austrian Ministry of Science, Research and Economy.

Jordheim, Helge og Tore Rem (red.) (2014): Hva skal vi med humaniora? Rapport om de humanistiske fagenes situasjon i Norge. Fritt Ord.

Kunnskapsdepartementet (2013a): Tildelingsbrev til universiteter og høyskoler for 2014. Hentet den 20. september 2016 fra https://www.regjeringen.no/no/dokumenter/tildelingsbrev-tiluniversiteter-og-hoys/id747533/

Kunnskapsdepartementet (2013b): Forskrift om tilsyn med utdanningskvaliteten i høyere utdanning (studietilsynsforskriften).

Kunnskapsdepartementet (2013C): Orientering om statsbudsjettet 2014 for universiteter og høyskoler.

Kunnskapsdepartementet (2015a): Konsentrasjon for kvalitet - Strukturreform i universitets- og høyskolesektoren. Meld. St. 18 (2014-2015) Melding til Stortinget.

Kunnskapsdepartementet (2015b): Hovedtrekkene i Meld.St. nr. 18 (2014-2015).

Københavns Universitet (2016): Kun få småfag overlever besparelser. Hentet den 20. september 2016 fra http://nyheder.ku.dk/alle_nyheder/2016/o4/kun-faa-smaafag-overlever-besparelser/

Lid, Stein Erik (2014): "Små" HF- og språkfag - kva seier Studiebarometeret oss.

Studiebarometeret: Rapport 9, NOKUT. 
Nasjonalt fakultetsmøte for HF-fag i Aten (2009): Oppfølging av nasjonal humaniorastrategi "Småfag" i humaniora -diskusjonsnotat.

Nasjonalt fakultetsmøte for humanistiske fag (2014): SAK i humaniora 2010-2014: Erfaringer og anbefalinger.

NIFU (2012): Er det noen SAK? Instituttsektorens rolle og organisering i Norge med spesiell vekt på samarbeid, arbeidsdeling og konsentrasjon (SAK). Rapport 50.

Nordic Council of Ministers ad hoc group for quality in higher education (2015): Student-centred approach from a Nordic perspective.

Nordisk ministerråd (2015): Sektorprogram for uddannelse og forskning - Danmarks formandskab for Nordisk Ministerråd 2015.

Nordisk ministerråd (2012): Sektorprogram for Ministerrådet for utdanning og forskning under det norske formannskapet i Nordisk ministerråd 2012.

Norges forskningsråd (2016): Fagevalueringer. Hentet den 20. september 2016 fra http://www.forskningsradet.no/no/Fagevalueringer/1182736860810

Norden (2015): Joint Degrees and the Nordic Countries, Nordic Master Programme - Legal and administrative obstacles. Nordisk Ministerråd.

Norden (2016): Nordiske aftaler. Hentet den 20. september 2016 fra http://www.norden.org/da/tema/uddannelse-og-forskning-i-norden/nordiske-aftaler

NOS-HS (2016). Hentet den 20. september 2016 fra http://www.nos-hs.org/sv_se

Sammenslutning af svenske universiteter (2009): Nationell samverkan inomutbildning i humaniora vid de svenska universiteten - en avsiktsförklaring. Hentet den 20. september 2016 fra http://www.gu.se/digitalAssets/1275/1275844_hfn-090611-05a.pdf

SUHF (2009): Rapport fra Språkgruppen. Hentet den 20. september 2016 fra http://www.suhf.se/MediaBinaryLoader.axd?MediaArchive_FilelD=c9794b13-077d-4331-8agc-

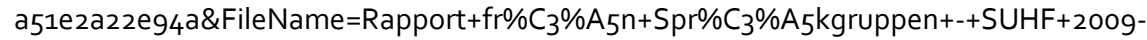
02_dnr+08-040_2009-06-02.pdf

SUHFs språkgrupp (2010): Digital språkundervisning del 3-Modellutveckling av digitale språkcentra. KK-stiftelsen.

Stjernø-utvalget (2008): Sett under ett - Ny struktur i høyere utdanning. Norges offentlige utredninger 3. Kunnskapsdepartementet.

The Research committee of the Norwegian Association of Higher Education Institutions, representatives from EUA and the Association of Nordic University Rectors Conferences (2012): The Svalbard Document. Konklusioner på baggrund af et møde i Longyearbyen, 20-22 April 2012

Uddannelses- og Forskningsministeriet (2016a): Dimensionering af de videregående uddannelser. Hentet den 20. september 2016 fra http://ufm.dk/uddannelse-oginstitutioner/videregaende-uddannelse/dimensionering

Uddannelses- og Forskningsministeriet (2016b): Nordisk samarbejde. Hentet den 20. september 2016 fra http://ufm.dk/uddannelse-oginstitutioner/internationalisering/internationalt-samarbejde-om-uddannelse/nordisksamarbejde

Universities Finland (2010): University reform in Finland 1.1.2010. Hentet den 20. september 2016 fra http://www.cimo.fi/instancedata/prime_product_julkaisu/cimo/embeds/cimowwwstructure/2 3947_University_reform_in_Finland.pdf 


\section{Sammenfatning}

Mange udsatte fag er i disse år i stor fare for at blive nedlagt, bl.a. på grund af begrænset optag ofte kombineret med stort frafald. De udsatte fag kæmper med kritisk masse og er pressede økonomisk og fagligt, fordi enhedsomkostningerne pr. studerende er høje. Fagene repræsenterer en kulturel og samfundsøkonomisk værdi, men der er ikke vilje eller økonomi til at tilføre dem væsentlige ressourcer. Derudover er der i de enkelte nordiske lande heller ikke et ønske om en væsentlig stigning i optaget på udsatte fag. Med afsæt i dette har denne undersøgelse til formål at undersøge, hvordan de udsatte fag kan blive styrket gennem nordisk SAK-samarbejde.

Udsatte fag defineres i denne undersøgelse som fag på niveau svarende til EOF 6 eller 7 med et større frafald end $30 \%$, og som har mindre end 20 optagne studerende per år, hvis de er på EQF-niveau 6, og mindre end 10 optagne per år, hvis de er på EQFniveau 7. Denne definition skal give et fælles nordisk grundlag for at diskutere udsatte fag og deres potentialer for nordisk SAK-samarbejde.

Den gennemførte desk research og de foretagne interview med repræsentanter fra de nordiske fagministerier peger på, at det er meget forskelligt, hvor meget de enkelte lande samt Færøerne, Grønland og Åland har fokus på samarbejde, arbejdsdeling og koncentration af fagmiljøer på nationalt plan såvel som mellem de nordiske landes institutioner og deres små fag som løsninger på de udsatte fags problemer. Der er imidlertid store potentialer i øget nordisk SAK-samarbejde, da der er en række fælles karakteristika, som gør sig gældende for udsatte humanistiske fag på tværs af Norden. Dette gælder blandt andet problemstillinger som kritisk masse, bæredygtig økonomi, studiemiljø samt internationalisering.

De interviewede prodekaner, dekaner, undervisere samt institut- og studieledere fremhæver i undersøgelsen, at SAK-samarbejde kan anvendes til at styrke de udsatte fag og overkomme de udfordringer, som udsatte fag kæmper med på tværs af de nordiske lande. Styrkerne ved SAK-samarbejde er, at det kan sikre større bredde og tyngde på de udsatte fag. Det kan ligeledes være med til at udvikle faget, give netværk på tværs af de nordiske lande, øge internationalisering, give økonomiske gevinster gennem stordriftsfordele samt skabe nordisk merværdi.

Der eksisterer imidlertid en række barrierer, som vanskeliggør nordisk SAKsamarbejde. Først og fremmest er der forskellige nationale rammer og institutionsspecifikke bestemmelser, som gør det vanskeligt at samarbejde. Dernæst kan manglende muligheder for at gennemføre den initiale økonomiske investering i samarbejdet være en hindring, da der typisk kan være store omkostninger forbundet med etablering af samarbejder bl.a. grundet det administrative arbejde. Endelig viser erfaringen, at koncentration af fag kan være en udfordring, da uddannelsesinstitutionerne ofte er interesserede $i$ at bevare fagene på uddannelsesstedet. Institutionernes ønske om autonomi og de interne konkurrenceforhold er ligeledes en hindring for gennemførsel af 
koncentration. De nævnte barrierer og modviljen fra institutionernes side står i vejen for styrkelse af de udsatte fag gennem SAK-samarbejder, der kan være med til at sikre fagenes overlevelse.

På baggrund af de identificerede fælles karakteristika for nordiske udsatte fag samt SAK-samarbejdes styrker og udfordringer, har vi undersøgt, hvilke samarbejdsmodeller, der vurderes som mest realisable og nyttige af undervisere samt institut- og studieledere på udsatte fag. Vi har gennem desk research og de gennemførte interview identificeret fire benyttede modeller for samarbejde. Modellerne er baseret på udvalgte cases for velfungerende SAK-samarbejder, som kan overføres til andre udsatte fag. Casene viser, at der kan være store fordele i at etablere SAK-samarbejde. De identificerede samarbejdsmodeller er kursussamarbejde; samarbejde om sprogfag med universiteter i det land, hvor sproget tales; fælles kandidatuddannelser (uddannelser på EOF 7 niveau) og sammenlægning. Især kursussamarbejde og fælles kandidatuddannelse vurderes af de udsatte fag til at være brugbare modeller, der kan anvendes i deres fag. De to typer af samarbejde stiller imidlertid et mobilitetskrav til de studerende og undervisere, hvilket kan være en udfordring. Online kurser og mobilitetsmidler fremhæves som instrumenter til at imødekomme denne udfordring. Samarbejde om sprogfag i landet, hvor sproget tales, vurderes som en god samarbejdsmodel, men er kun relevant for sprogfag. De interviewede undervisere, institut- og studieledere fremhæver desuden, at den sidste model, koncentration, har sine fordele, men kræver koordinering og organisering fra ministerielt eller nordisk niveau.

Repræsentanter fra udsatte fag ser generelt stort potentiale i nordiske SAKsamarbejder, især på kandidatniveau (EOF 7), som i højere grad er udfordret på kritisk masse. Det fremhæves, at SAK-samarbejde kan bidrage til fagudvikling, styrke de skandinaviske sprog, styrke kvaliteten, give større diversitet og øge studentergrundlaget. Der er som tidligere påpeget imidlertid stadig en række barrierer, der skal overkommes, såsom bureaukratiske udfordringer, manglende finansiering og intern modstand på institutionerne. Er det muligt at komme ud over de barrierer, kan SAK-samarbejde være til fordel for både de studerende, fagmiljøerne, uddannelsesinstitutionerne og de nordiske samfund. Vi har i det følgende udarbejdet en række anbefalinger, som kan bidrage til at mindske de barrierer, der er identificeret i undersøgelsen. 


\section{Appendix 1: List of interviewees}

Table 9: Representatives of ministries

\begin{tabular}{lll} 
Title & Agency & Country \\
Head of Section & Danish Agency for Higher Education & Denmark \\
Senior Advisor & The Norwegian Association of Higher Education Institutions & Norway \\
Counsellor of Education & Department for Higher Education and Science Policy & Finland \\
Executive Director & Finnish Council of University Rectors & Finland \\
Senior Advisor & Department of Education and Science & Iceland \\
Head of Department of Education & Ministry of Education, Culture, Research and Church Affairs & Greenland \\
University Rector & University of the Faroe Islands & Faroe Islands \\
Advisor & Ministry of Education, Research and Culture & Faroe Islands \\
\hline
\end{tabular}

Table 10: Deans and associate deans

\begin{tabular}{lll} 
Title & HEI & Country \\
\hline Dean & Stockholm University & Sweden \\
Associate Dean for Undergraduate Education & Lund University & Sweden \\
Associate Dean of Education & University of Copenhagen & Denmark \\
Associate Dean of Education & Aarhus University & Denmark \\
Associate Dean of Education & University of Oslo & Norway \\
Associate Dean of Education & UiT - The Arctic University of Norway & Norway \\
Dean & University of the Faroe Islands & Faroe Islands \\
Dean & University of Iceland & Iceland \\
Dean & University of Eastern Finland & Finland \\
Associate Dean & University of Finland & Finland \\
Dean & University of Turku & Finland \\
\hline
\end{tabular}


Table 11: Heads of department, heads of study and lecturers

Title HEI

Associate Professor

Associate Professor

Head of Department

Course co-ordinator

Head of Studies

Head of Studies

Head of Department

Associate Professor

Associate Professor

Associate Professor

Head of Studies

Head of Studies

Associate Professor

Professor

Head of Studies

Professor

Assistant Professor

Head of Studies

Professor

Head of Studies
University of Tampere

Mid Sweden University

Aarhus University

The Norwegian University of Science and Technology

Stockholm University

University of Southern Denmark

Stockholm University

Uppsala

Norwegian Academy of Music

University of Copenhagen

University of Helsinki

University of Oslo

Lund University

Aarhus University

University of Oslo

University of Iceland

University of Copenhagen

University of Copenhagen

University of Oslo

Stockholm University

University of Turku
Comparative Literature

Comparative Literature

French

Comparative Literature

Archaeology

Philosophy

Linguistics

Musicology

Musicology

Italian

Classical Philology

Classical Philology

East European Studies

Viking and Medieval Norse Studies

Viking and Medieval Norse Studies

Viking and Medieval Norse Studies

China Studies

Balkan Studies

China Studies

China Studies

German
Finland

Sweden

Denmark

Norway

Sweden

Denmark

Sweden

Sweden

Norway

Denmark

Finland

Norway

Sweden

Denmark

Norway

Iceland

Denmark

Denmark

Norway

Sweden

Finland 


\section{Appendix 2: Note on quantitative indicators}

This section consists of a systematic presentation of indicators, comparability and how these correlate to vulnerable subjects in the Nordic countries. The aim is to highlight both the potential and the limitations in the available data.

\section{Data sources}

The data on intake to bachelor programmes in Denmark was acquired from the Coordinated Admission System (KOT). Data on master's programmes was acquired from Statistics Denmark, which works with more general humanities categories than KOT, e.g., the Romance Languages category, which covers French, Spanish, Italian and Portuguese. It is, therefore, not possible to identify all of the small subjects at master's level in Denmark, as some of the more general categories with student intake of more than 10 may actually be small subjects at individual programme level. The Coordinated Admission System does not divide study programmes up into general categories. Nonhumanities study programmes have therefore been excluded on a discretionary basis, informed by data from Statistics Denmark.

Enrolment statistics from the Swedish Council for Higher Education do not distinguish between bachelor and master's programmes. If "master" or "magister" (one-year post-master's qualification) is part of the programme title, it is categorised as a master's programme. As the world "bachelor" does not feature in any of the programme names, programmes without specific level descriptions have been categorised as bachelor programmes. In reality, therefore, there may be fewer bachelor and more master's programmes than shown. Statistics Sweden's StatBank does not divide study programmes up into general categories. Non-humanities study programmes have therefore been excluded on a discretionary basis, informed by data from Studerna.nu, which is generated by the Association of Swedish Higher Education (UHR).

In the case of Finland, we were unable to obtain data all the way down to programme level. Finland uses broad categories such as humanities, music, art and theology. Based on this data, it is possible to identify small subjects in art, drama, theology and the humanities in general, but not to identify specific study programmes. The number of small subjects in Finland should, therefore, be interpreted as an absolute minimum.

Iceland does not have data for intake, but it does have data on the number of students registered on study programmes in 2013 . Their postgraduate diploma is categorised as a master's programme (EQF7), while the undergraduate diploma is 
classed as a bachelor programme (EQF6). However, the diploma programmes vary in length and are probably shorter than the respective full bachelor and master's programmes. This means that some of the diploma programmes may not be small subjects, so the figures should be interpreted as a maximum. The data does not make it possible to divide the programmes up into general categories. Non-humanities study programmes have therefore been excluded on a discretionary basis. The sources used were:

Denmark:

- KOT: Coordinated Admission System.

- UFM: Ministry of Higher Education and Science.

- DST: Statistics Denmark.

Sweden:

- UHR: Association of Swedish Higher Education.

- SCB: Statistics Sweden.

- UKA: Swedish Higher Education Authority.

Norway:

- NSD - DBH: Norwegian Centre for Research data - Database for Statistics on Higher Education.

- SSB: Statistics Norway.

Finland:

- Vipunen: Education Statistics Finland.

- Tilastokeskus: Statistics Finland.

Greenland:

- Naatsorsueqqissaartarfik: Statistics Greenland.

Iceland:

- Hagstofa: Statistics Iceland.

The Faroe Islands:

- Hagstova: Statistics Faroe Islands. 


\section{Correlation of indicators}

Generally speaking, it is possible to compare indicators from the bigger countries for intake and dropout rates. However, this comparison requires broad definitions and assumptions. This is due to the fact that the different countries have different definitions and categorisations, as per the table below. One exception is Iceland, for which we only have figures for the numbers of registered students. For this reason, the data for Iceland is presented separately. Dropout rates for Sweden and Norway are estimates based on the numbers for completed programmes, because there is no centralised data for this variable. Finnish data on dropout rates is still unavailable. Data on dropout rates is also still lacking for many of the specific study programmes in all of the countries.

We concluded that it would be problematic to try and correlate the various key indicators for vulnerability across the Nordic countries. The reason for this is that individual countries use different categorisations when compiling their figures:

- Numbers of students and dropout rates are (mostly) compiled for specific study programmes.

- Numbers of academic staff are compiled for main area or faculty.

- Budgets are compiled by main area or faculty.

This means that it is only possible to gather data at the broadest level of categorisation - usually at HEl level. However, in some cases it is possible to correlate data at a more detailed level, provided that not all of the countries or variables are included.

As far as possible, the data for 2014 was used, but there are certain deviations because of lack of data:

- Sweden, number of academic staff: 2011.

- Sweden, budget: 2013.

- Sweden, student population: 2008.

- Iceland, budget: Year unknown. ${ }^{13}$

There are data on all indicators (except for dropout rates and completion times) for the bigger countries: Denmark, Sweden, Norway, Iceland and Finland. It has not been possible to obtain data on all indicators for the smaller countries: Iceland, Greenland, Åland and the Faroe Islands. No humanities study programmes run in Åland, and so it has not been included in the analysis, aside from a brief mention in the section on the range of courses available.

${ }_{13}$ The latest figures probably date from 2014 


\section{Comparison across countries}

It was not possible to collect data based on exactly the same definitions for all of the countries. This makes it difficult to make a direct comparison across all of the countries, or to create a single database for all of the countries' data. For the four big countries (Denmark, Sweden, Norway and Finland) and Greenland, it is possible to compare intake, which must be considered the most important parameter. It is also possible to compare budgets directly at HEI level for the big countries and Iceland. It is possible to compare numbers of academic staff for all of the big countries at HEl level, and at departmental level for Denmark, Sweden and Finland.

\section{Information about the database for all indicators}

We have compiled all of the available data in a database of indicators that will be made available to the Nordic Council of Ministers at the end of this project. "Intake" will be the controlling variable in the database. In other words, all of the other variables are defined on the basis of the categorisation for the variable "intake". The database only includes data that can analysed down to this level, i.e. intake and dropout.

\section{Summary of data in table format}

Table 12: Summary of indicators per variable

\begin{tabular}{|c|c|c|}
\hline Variable & Ability to correlate with other variables & Ability to compare countries \\
\hline Intake & $\begin{array}{l}\text { Can be correlated with completion data in } \\
\text { Denmark, Norway, Finland and Greenland, } \\
\text { and with student numbers in Norway, Finland } \\
\text { and Greenland. }\end{array}$ & $\begin{array}{l}\text { Comparison possible across the bigger countries } \\
\text { at study-programme level. Data about specific } \\
\text { study programmes can also be derived from the } \\
\text { Greenland data. }\end{array}$ \\
\hline Dropout rates & Only data from Denmark and Greenland. & Only data from Denmark and Greenland. \\
\hline Completion time & Only data from Denmark. & Only data from Denmark. \\
\hline Completion rate & $\begin{array}{l}\text { Can be correlated with intake in Denmark, } \\
\text { Norway, Finland and Greenland, and with } \\
\text { student numbers in Norway, Finland and } \\
\text { Greenland. }\end{array}$ & $\begin{array}{l}\text { Comparison possible between the bigger } \\
\text { countries at study-programme level except for } \\
\text { Sweden, which operates with broad categories } \\
\text { for the humanities. }\end{array}$ \\
\hline Student numbers & $\begin{array}{l}\text { Can be correlated with intake in Norway, } \\
\text { Finland and Greenland and completion data } \\
\text { in Sweden (2008/2009), Norway, Finland and } \\
\text { Greenland. }\end{array}$ & $\begin{array}{l}\text { Major differences in definitions and } \\
\text { categorisation. Figures are available for all } \\
\text { countries. }\end{array}$ \\
\hline Academic staff & $\begin{array}{l}\text { Can be correlated with intake, etc. by raising } \\
\text { categorisation to faculty level. Variations in } \\
\text { definitions. }\end{array}$ & Can be compared at faculty/overall subject level. \\
\hline Budget & $\begin{array}{l}\text { Can be correlated with number of academic } \\
\text { staff at faculty/subject level. Note the } \\
\text { variation in definitions of faculty/subject + } \\
\text { endogeneity problems. }\end{array}$ & $\begin{array}{l}\text { Major differences in the definition of budget } \\
\text { (income vs. expenses }+ \text { which items are } \\
\text { included). In some cases, the budget is calculated } \\
\text { as a function of the number of academic staff } \\
\text { (Norway and Sweden). }\end{array}$ \\
\hline
\end{tabular}


Table 13: Summary of definitions and categories

\begin{tabular}{|c|c|c|c|}
\hline Variable/Country & Year & Definition & Most detailed level of categorisation \\
\hline \multicolumn{4}{|l|}{ Intake } \\
\hline Denmark & $2010-2014$ & $\begin{array}{l}\text { Number of individuals who enrolled in the } \\
\text { institution/programme in the period from } 1 \\
\text { October of the previous year to } 30 \text { September } \\
\text { of the current year. For BA programmes, } \\
\text { summer enrolment is also included for } 2015 \text {. }\end{array}$ & $\begin{array}{l}\text { Specific study programme, level, institution } \\
\text { and campus. }\end{array}$ \\
\hline Sweden & 2014 & $\begin{array}{l}\text { Number of students enrolled for autumn } \\
\text { semester, enrolment quotas } 1 \& 2 \text {. }\end{array}$ & $\begin{array}{l}\text { Specific study programme, (partial) level and } \\
\text { institution. Non-humanities manually } \\
\text { removed. }\end{array}$ \\
\hline Norway & 2014 & $\begin{array}{l}\text { Enrolment for autumn semester. The criteria } \\
\text { for intake are that the student has registered } \\
\text { and paid the fees for the semester at the time } \\
\text { of data extraction. If the student has a study } \\
\text { plan, this must be confirmed. Students who } \\
\text { take 6o ECTS credits or more must have an } \\
\text { approved study plan. }\end{array}$ & $\begin{array}{l}\text { Specific study programme, level and } \\
\text { institution. }\end{array}$ \\
\hline Finland & 2014 & $\begin{array}{l}\text { Number of students who enrol the first time as } \\
\text { distance learning or campus-based students, } \\
\text { respectively. }\end{array}$ & Programme, level and HEI. \\
\hline Iceland & $2007-2013$ & $\begin{array}{l}\text { No data, only information on number of } \\
\text { registered students. }\end{array}$ & $\begin{array}{l}\text { Study-programme categorisation based on } \\
\text { ISCED97, level and institution. }\end{array}$ \\
\hline Greenland & $2003-2015$ & Study commenced & $\begin{array}{l}\text { Study-programme categorisation based on } \\
\text { ISCED2011, level and institution Details of } \\
\text { specific study programmes can be } \\
\text { extrapolated from the University of Greenland } \\
\text { website. }\end{array}$ \\
\hline \multicolumn{4}{|l|}{ Dropout rates } \\
\hline Denmark & $2010-2014$ & $\begin{array}{l}\text { Proportion of students who drop out during the } \\
\text { first year. Available only for bachelor level. }\end{array}$ & $\begin{array}{l}\text { Specific study programme, level, } \mathrm{HEI} \text { and } \\
\text { campus. }\end{array}$ \\
\hline Greenland & $2003-2015$ & Number of interrupted studies & $\begin{array}{l}\text { Programme categorisation based on } \\
\text { ISCED } 2011 \text { (but specific programmes can be } \\
\text { extrapolated), level and HEI. }\end{array}$ \\
\hline Sweden & & $\begin{array}{l}\text { National data not compiled, but estimated on } \\
\text { the basis of intake and the number of } \\
\text { completed study programmes. }\end{array}$ & No data exists. \\
\hline Norway & & $\begin{array}{l}\text { National data not compiled, but estimated on } \\
\text { the basis of intake and the number of } \\
\text { completed study programmes. }\end{array}$ & No data exists. \\
\hline Finland & & Data not compiled nationally. & No data exists. \\
\hline Iceland & & Data not compiled at programme or HEI level. & Not at programme nor HEI level. \\
\hline \multicolumn{4}{|l|}{ Completion time } \\
\hline Denmark & 2010-2014 & No. of months past prescribed period of study & Specific programme, level, $\mathrm{HEI}$ and campus. \\
\hline Sweden & & Data not compiled nationally. & No data exists. \\
\hline Norway & & Data not compiled nationally. & No data exists. \\
\hline Finland & & Data not compiled nationally. & No data. \\
\hline Iceland & & Data not compiled nationally. & No data. \\
\hline
\end{tabular}




\begin{tabular}{|c|c|c|c|}
\hline Variable/Country & Year & Definition & Most detailed level of categorisation \\
\hline \multicolumn{4}{|l|}{ Completion rate } \\
\hline Denmark & $2010-2014$ & Number of graduates (people). & $\begin{array}{l}\text { Specific study programme, level, } \mathrm{HEI} \text { and } \\
\text { campus. }\end{array}$ \\
\hline Greenland & $2003-2015$ & Completed studies. & $\begin{array}{l}\text { Specific study programme (extrapolated), level } \\
\text { and HEI. }\end{array}$ \\
\hline Sweden & $2008 / 2009$ & $\begin{array}{l}\text { Number of graduates. Also available for } \\
\text { academic year } 2014 / 2015 \text {, but with different } \\
\text { categorisation that cannot be correlated with } \\
\text { other variables. }\end{array}$ & HEI and "topic". \\
\hline Norway & 2015 & $\begin{array}{l}\text { No. of students who attained all ECTS credits } \\
\text { on the programme. }\end{array}$ & Specific programme, level and HEI. \\
\hline Finland & 2014 & Exams at $\mathrm{HEI}$. & Specific programme, level and $\mathrm{HEI}$. \\
\hline Iceland & & No data. & Available at programme level but not $\mathrm{HEI}$ level. \\
\hline \multicolumn{4}{|l|}{ Academic staff } \\
\hline Denmark & 2014 & $\begin{array}{l}\text { Number of FTEs (full-time equivalents): Full- } \\
\text { time and part-time academic staff. }\end{array}$ & Institution + main area. \\
\hline Sweden & 2011 & $\begin{array}{l}\text { Number of full-time equivalents: Researchers + } \\
\text { lecturers. }\end{array}$ & $\mathrm{HEI}$ and research topic. \\
\hline Norway & 2014 & FTEs by lecturers and researchers. & Departmental level. \\
\hline Finland & 2014 & Number of FTEs: Teaching and research staff. & $\mathrm{HEI}$ and research topic. \\
\hline Iceland & & No data. & No data. \\
\hline \multicolumn{4}{|l|}{ Budget } \\
\hline Denmark & 2014 & Costs in 2014 (DKK million, current prices). & HEI and faculty. \\
\hline Sweden & $2013^{14}$ & $\begin{array}{l}\text { Operating expenses for research and teaching, } \\
\text { DKK million. At current prices, by research } \\
\text { topic. }\end{array}$ & $\mathrm{HEI}$ and research topic. \\
\hline Norway & 2014 & $\begin{array}{l}\text { Grant- and foundation-funded activity, } \\
\text { excluding from the Research Council of Norway } \\
\text { (NFR), Regional Research Funds (RFF) and the } \\
\text { EU Framework Programme. }\end{array}$ & HEI level. \\
\hline Finland & 2014 & Total external funding. & $\mathrm{HEI}$ and research topic. \\
\hline Iceland & Unknown & Government funding for $\mathrm{HEI}$. & HEl. \\
\hline
\end{tabular}

\section{National overviews}

\section{Denmark}

In the period since 2014 until the time of writing, another parameter has been introduced in Denmark that may affect the base figures, in particular for intake to small study programmes. In the period 2015-2018, student numbers on individual programmes will be rationalised (referred to as "dimensioning") and this may have an impact on which subjects/programmes are categorised as vulnerable.

14 The financial statistics will be updated in October 2016. The final report will include the latest figures. 


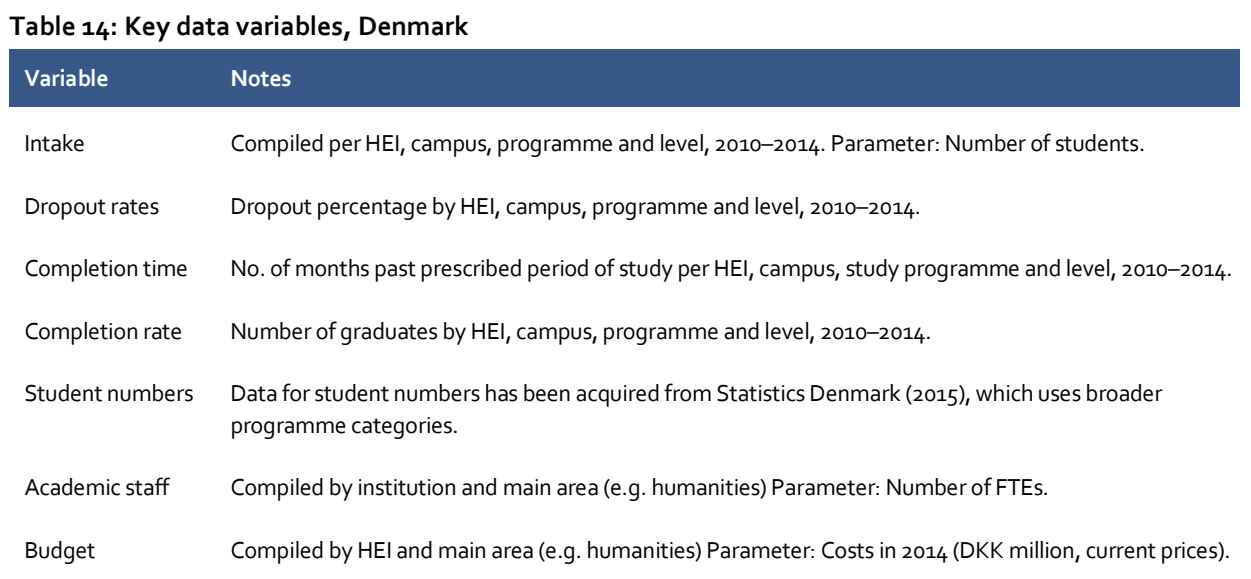

\section{Sweden}

The Swedish Higher Education Authority (uka.se) categorises study programmes differently, depending on the year to which the data refers. From 2009, they have used the categorisation "ämne" (subject), which is further subdivided into 180 groupings for registered students. In their tables, however, this categorisation is used for figures dating back to autumn 2007. The categorisation used since 2009 is a revised version of the previous subject categorisation. The statistics database is currently in the process of updating pre-2009 tables to reflect the new classification.

The completion data have been updated in line with the new categorisation in the tables up to and including 2008. This means that for 2007 and 2008, completion and student numbers can be correlated with the latest ämne (subject) categorisation. Student numbers for budget year 2008 were calculated as the average number in the autumn and spring semesters. In 2007, a new system was introduced in Sweden for exams and studying, which is why the statistics changed in 2008. The more recent completion data are in line with the SUN 2000 classification in main areas, which the data for student numbers does not follow in some of the tables. The most recent figures for completion cannot, therefore, be correlated with other variables. Even for academic year 2008/2009, only the completion and student population variables can be correlated. The intake data is for specific programmes and cannot be directly correlated with any variable, other than by manual recoding (which entails a risk of errors). 
Table 15: Key data variables, Sweden

Variable

Intake

Dropout rates

Completion time

Completion rate

Student numbers

No. of academic staff

Budget

\section{Notes}

Compiled by HEl, specific programme and (partly) by level. Non-humanities programmes were excluded manually.

Parameter: Student numbers.

No data - estimated from completion figures.

No data.

Number of degree examinations by level and "main area" for 2014/2015 (academic year)/number of degree exams by level and "ämne" (subject) for 2008 (budget year).

Registered students by semester and "ämne" (subject), 2007-2015. The last year that can be correlated with other variables is 2008 . Since then, categorisation has been based on areas rather than subjects.

Compiled by HEl and research topic (e.g., "Romance Languages").

Parameter: Number of full-time equivalents (FTEs) -researchers/lecturers (2011).

Compiled by HEl and research topic (albeit not based on precisely the same categories as above - a manual conversion would make it possible to correlate directly with numbers of academic staff).

Parameter: Operating costs for R\&D in the university college sector - SKK million in current prices by research topic, $\mathrm{HEI}$ and funding source, every second year (2013).

\section{Norway}

The budget figures for Norway are calculated as grant- and foundation-funded activity, excluding from the Research Council of Norway (NFR), Regional Research Funds (RFF) and the EU Framework Programme.

Table 16: Key data variables, Norway

\begin{tabular}{|c|c|}
\hline Variable & Notes \\
\hline Intake & $\begin{array}{l}\text { Compiled by HEl, programme under "Humanities and ethics subjects" and level, autumn } 201 . \\
\text { Parameter: Student numbers. }\end{array}$ \\
\hline Dropout rates & No data - estimated from completion figures. \\
\hline Completion time & No data. \\
\hline Completion rate & $\begin{array}{l}\text { Number of graduates compiled by HEI and programme, } 2014 \text { (autumn + spring). Level can be } \\
\text { deduced by correlation with intake data. }\end{array}$ \\
\hline Student numbers & Registered students by HEl, programme and level, autumn 2014 . \\
\hline Academic staff & $\begin{array}{l}\text { Compiled at } \mathrm{HEI} \text { and department level. } \\
\text { Parameter: Lecturers and researchers, FTEs. }\end{array}$ \\
\hline Budget & $\begin{array}{l}\text { Compiled at HEl and department level. } \\
\text { Parameter: Grant- and Public Sector Consultancy-funded activity, minus funding from the } \\
\text { Research Council of Norway (NFR), Regional Research Funds (RFF) and EU Framework } \\
\text { Programme, } \rightarrow \text { divided by members of academic staff. }\end{array}$ \\
\hline
\end{tabular}




\section{Finland}

Table 17: Key data variables, Finland

\begin{tabular}{ll} 
Variable & Notes \\
\hline Intake & $\begin{array}{l}\text { Compiled by HEI, programme and level under "Arts \& Humanities", 2014. } \\
\text { Parameter: New students. }\end{array}$ \\
Dropout rates & Data is available, but it is logically inconsistent, with many gaps \\
Completion time & No data. \\
Completion rate & No. of exams by HEI, level and programme within Arts \& Humanities, 2014. \\
Student numbers & Registered students by HEl, programme and level under Arts \& Humanities, 2014. \\
Academic staff & $\begin{array}{l}\text { By department and research topic (e.g. "Art and Design"). } \\
\text { Parameter: Number of FTEs: }\end{array}$ \\
Budget & $\begin{array}{l}\text { By HEl and research topic (e.g. "Art and Design"). } \\
\text { Parameter: Total expenditure. }\end{array}$
\end{tabular}

Iceland

Table 18: Key data variables, Iceland

$\begin{array}{ll}\text { Variable } & \text { Notes } \\ \text { Intake } & \text { No data. } \\ \text { Dropout rates } & \text { Not compiled at programme or HEl level. } \\ \text { Completion time } & \text { No data. } \\ \text { Completion rate } & \text { Only by programme, not by HEI. } \\ \text { Student numbers } & \begin{array}{l}\text { Registered students by HEI, ISCED97 programme categories under Humanities \& Arts, and level, } \\ 2007-2013 .\end{array} \\ \text { Academic staff } & \text { No data. } \\ \text { Budget } & \begin{array}{l}\text { By HEI. } \\ \text { Parameter: Government funding for HEI. }\end{array}\end{array}$

\section{Greenland}

Greenland has only one university, Ilisimatusarfik - University of Greenland, which runs two humanities programmes: Theology; and Language, Literature and Media. Theology is not available at master's level. 
Table 19: Key data variables, Greenland

Variable Notes

Intake Studies commenced, by HEI, ISCED11 programme categories (specific programmes can be extrapolated) under Arts and Humanities, and level, 2003-2015.

Dropout rates Interrupted studies by HEI, ISCED11 programme categories (specific programmes can be extrapolated) under Arts and Humanities, and level, 2003-2015.

Completion time No data.

Completion rate Completed studies by HEI, ISCED11 programme categories (specific programmes can be extrapolated) under Arts and Humanities, and level, 2003-2015.

Student numbers Active students by HEI, ISCED11 programme categories (specific programmes can be extrapolated) under Arts and Humanities, and level, 2003-2015.*

Academic staff No data

Budget No data.

\section{Faroe Islands}

The University of the Faroe Islands, the only university in the Faroe Islands, only has one humanities subject: Faroese Language and Literature.

Table 20: Key data variables, Faroe Islands

\begin{tabular}{ll} 
Variable & Notes \\
Intake & No data. \\
Dropout rates & No data. \\
Completion time & No data. \\
Completion rate & No data. \\
Student numbers & $\begin{array}{l}\text { Registered students, by HEl, programme and level, academic years 1998/99-2010/11. } \\
\text { Parameter: Registered students at } 1 \text { February for the years 1998/99-2005/06 and 2009/10, and at } 1 \\
\text { October for the years 2006/07-2008/09 and 2010/11. }\end{array}$ \\
Academic staff & No data. \\
Budget & $\begin{array}{l}\text { At department level and centres. } \\
\text { Parameter: Budget. }\end{array}$ \\
\hline
\end{tabular}

\section{Åland}

Åland University of Applied Sciences, the only university in Åland, does not run any humanities programmes. It offers courses such as Philosophy and German via the Open University and in collaboration with Åbo Akademi University, but does not run full humanities programmes. Åland was therefore not relevant during the mapping exercise of small humanities subject areas in the Nordic Region. 
Nordic Council of Ministers

Ved Stranden 18

DK-1061 Copenhagen $K$

www.norden.org

\section{Higher Education in the Nordic Countries}

The Nordic countries have a lot in common. We share the same values and culture in education, and vulnerable subjects face many of the same challenges across the Region. This makes it advantageous for us to work together on enhancing Nordic competencies and competitiveness and to generate Nordic added value by working together on these vulnerable subject areas.

A Nordic approach will generate synergies that would not be possible to achieve at national level. Nordic work on Collaboration, Specialisation and Concentration (CSC) can help overcome the challenges faced by vulnerable study programmes all over the Region. From this starting point, the study looks at how work on CSC can help maintain sustainable, high-quality study programmes throughout the Nordic Region. 